\title{
Bułgarzy i Bułgaria w ostatniej ćwierci wieku XIX w publikacjach Jana Grzegorzewskiego (kultura, ludność, gospodarka)
}

Zarys treści: Jan Grzegorzewski, wybitny polski slawista i orientalista odbył na przełomie wieków XIX i XX. kilka podróży po Bałkanach. W ich trakcie dokonał wnikliwych obserwacji miejscowych stosunków społecznych, politycznych i ekonomicznych, z których wnioski zawarł w kilku opublikowanych na przełomie XIX i XX w. książkach i artykułach. Miejsce szczególne w jego pracy badawczej zajmowała Bułgaria. Niniejszy artykuł jest prezentacją obrazu tego kraju postrzeganego przez autora przez pryzmat trzech głównych, podjętych $\mathrm{w}$ jego pracach wątków - kultury, społeczeństwa i gospodarki.

Outline of content: Jan Grzegorzewski, an outstanding Polish Slavic philologist and Orientalists, made at the turn of the $20^{\text {th }}$ century several voyages throughout the Balkans. During his trips he made careful and detailed observations of local social, political and economic relations, and publicised the conclusions in several of his books and articles published at the end of the $19^{\text {th }}$ and early $20^{\text {th }}$ century. Special place in his research work was occupied by Bulgaria. The purpose of this study is to present the image of this country as seen by Grzegorzewski through the prism of three central themes brought up in his texts: culture, society and economy.

Słowa kluczowe: Jan Grzegorzewski, Bułgaria, egzarchat bułgarski, szkolnictwo, rolnictwo, handel

Keywords: Jan Grzegorzewski, Bulgaria, Bulgarian Exarchate, education, agriculture, trade

Przystępując do analizy twórczości Jan Grzegorzewskiego, stwierdzić wypada, że był on jest postacią równie niezwykłą, co nieznaną. Jakkolwiek współcześnie dość często zaliczany jest do grona najbardziej zasłużonych polskich etnografów, etnologów, slawistów czy orientalistów, gruntowniejsza wiedza na temat jego dokonań nie jest znana szerszemu gronu odbiorców. Kwestie te na przestrzeni ostatnich dziesięcioleci tylko okazjonalnie podejmowane były w polskiej literaturze naukowej, 
stając się tematem nielicznych artykułów ${ }^{1}$, a wyniki jego dogłębnych obserwacji stosunkowo rzadko wykorzystywano nawet w ramach szerszych rozważań z zakresu etnografii i orientalistyki, a zwłaszcza historii ${ }^{2}$. Fakt ten niewątpliwie motywuje do tego, aby przybliżyć nieco postać Jana Grzegorzewskiego, który przez kilka dziesięcioleci był blisko związany z Bułgarią i jako naoczny świadek obserwował zarówno rozgrywające się tam wydarzenia natury politycznej, jak i procesy zachodzące w szeroko rozumianym życiu społecznym. Podjęcie tematu wydaje się tym bardziej zasadne, że biografia Grzegorzewskiego jest nie tylko niezwykle ciekawa, ale także w wielu miejscach spowita swego rodzaju „mgłą tajemniczości”3.

Wiadomo, że Jan Grzegorzewski urodził się we wsi Szulajki koło Zawiahela na Wołyniu, ale ustalenie dokładnej daty nastręcza wiele problemów. Najczęściej przyjmuje się, że była to druga połowa lat 40. XIX w., a dokładniej rok 1846 lub 1849. Sam Grzegorzewski w napisanym przez siebie ok. 1920 r. życiorysie wskazał tę drugą datę, ale wszelkie próby jej potwierdzenia są z góry skazane na niepowodzenie z powodu braku jakichkolwiek urzędowych dokumentów pozwalających na jej weryfikację ${ }^{4}$. Nie mamy także żadnych bliższych informacji na temat młodości Grzegorzewskiego. Wiadomo, że uczęszczał do gimnazjum w Żytomierzu, a następnie rozpoczął studia slawistyczne na uniwersytecie w Odessie. Trudno jednak jednoznacznie stwierdzić, czy studia te ukończył. Pewne jest jednak to, że do roku 1870 dużo podróżował, odwiedził m.in. Bliski Wschód, Azję i północną Afrykę. . Następnie osiadł w Galicji, by w dobie wojny rosyjsko-tureckiej 1877-

\footnotetext{
${ }^{1}$ M.in. J. Reychman, Zasługi Jana Grzegorzewskiego na polu zbliżenia kulturalnego polsko-bułgarskiego, w: Stosunki literackie polsko-bułgarskie, red. J. Śliziński, Wrocław 1971; idem, W ośrodkach orientalnych i orientalistycznych Bułgarii, „Przegląd Orientalistyczny” 1957, nr 1; Z. Klejn, Polskie stronice w bułgarskiej historii, „Mazowieckie Studia Historyczne” 2 (1998); K. Dobosz, Początki i pierwszy tom „Rocznika Orientalistycznego”. Przyczynek do dziejów czasopisma, „LingVaria” 7 (2012), nr 2; U. Kaczmarek, Jan Grzegorzewski - „pierwszy” polski orientalista, „Sprawy Wschodnie" 2002, nr 1; J. Zborowski, Historia pewnej książki. Wspomnienie o Janie Grzegorzewskim, „Rocznik Podhalański” 5 (1992); J. Tyszkiewicz, Jan Grzegorzewski w ostatnich latach życia: 1916-1922, „Almanach Karaimski” 4 (2015); J. Rubacha, Obraz przemian politycznych w Bułgarii w książce Jana Grzegorzewskiego „Rok przewrotów. (Bułgarya 1885/6)”, w: Wokót reportażu podróżniczego, red. D. Rott, Katowice 2007.

2 M.in. J. Reychman, Peleryna, ciupaga i znak tajemny, Kraków 1971; Z. Klejn, Polskie ślady w budowie nowożytnej Bułgarii, Łowicz 1999; M. Hoszowska, Ludwik Finkel i Akademia Umiejętności. Z dziejów współpracy naukowej Lwowa i Karkowa na przełomie XIX i XX wieku, Rzeszów 2011.

${ }^{3}$ Kwestie te podnoszono wielokrotnie, a w przypisywanym Andrzejowi Gawrońskimu i opublikowanym na łamach „Rocznika Orientalistycznego” w 1925 r. nekrologu Grzegorzewskiego, autor napisał: „Wiadomości biograficznych o Janie Grzegorzewskim nie możemy podać ani wiele, ani pewnych, bo wszystkie, jakie mamy, o ile tyczą lat młodszych, przed rokiem 1876, płyną z jednego źródła: własnych Jego opowiadań, wiadomo zaś tym, którzy go znali, że w opowiadaniach tych plątały się Dichtung und Wahrheit w tak nierozwikłany sposób, że łatwiej na ich tle napisać arcyciekawą powieść obyczajową niż ścisły życiorys”, K. Dobosz, op. cit., s. 177-178, przyp. 1.

${ }^{4}$ Ibidem, s. 177.

${ }^{5}$ Pokłosiem tych podróży była jego praca: $Z$ pod nieba wschodniego. Nowele i fragmenty podróży, wydana we Lwowie w 1904 r. Na ten temat piszą także: A. Chłoniewski, Nieśmiertelni. Fotografie
} 
1878 podążyć na Bałkany w charakterze korespondenta wojennego francuskiego pisma „Le Figaro” i polskojęzycznych gazet w Galicji i Królestwie Polskim: „Gazety Codziennej” i „Gazety Warszawskiej”". Nie ulega wątpliwości, że to właśnie wówczas zrodziło się jego zainteresowanie tą częścią Europy, które z biegiem czasu przerodziło się w swego rodzaju fascynację. Stąd też w kolejnych latach Grzegorzewski wielokrotnie podróżował po Bałkanach ${ }^{7}$, a szczególnie często odwiedzał darzoną przez siebie dużą sympatią Bułgarię. Trudno zatem się dziwić, że poczynione przez niego obserwacje miejscowych stosunków politycznych, ekonomicznych i społecznych stały się kanwą pierwszych jego publikacji, tj. artykułów: Spótczesna Bułgarya, zamieszczonego w warszawskim czasopiśmie „Ateneum” w 1883 r. ${ }^{8}$, i Stosunki handlowe $z$ Bułgarya oraz Szkolnictwo $w$ Bułgaryi opublikowane w lwowskim „Przeglądzie Powszechnym” w 1887 r. ${ }^{9}$ W tym czasie Grzegorzewski, jako korespondent prasy brytyjskiej, francuskiej i polskiej, wraz z Antonim Piotrowskim po raz kolejny odwiedził Bułgarię w latach 1885-1886, w związku z zachodzącymi w tym kraju dynamicznymi wydarzeniami. Pokłosiem tej wizyty była wydana we Lwowie w 1900 r. praca zatytułowana Rok przewrotów (Bułgarya 1885/6) ${ }^{10}$.

Po powrocie na ziemie polskie, ok. 1890 r., przystąpił do realizacji idei stworzenia w Warszawie szkoły handlowej, która kształcić miała specjalistów do handlu ze Wschodem, a w ramach podjętych wówczas prac, zajął się m.in. opracowywaniem podręczników do nauki języków bałkańskich i bliskowschodnich, w tym: bułgarskiego, rumuńskiego, tureckiego i perskiego ${ }^{11}$. Mimo poparcia, jakiego udzielił Grzegorzewskiemu Ludwik Krasiński - jeden z najbogatszych ziemian w Królestwie Polskim i prezes oddziału Towarzystwa Popierania Rosyjskiego Przemysłu i Handlu w Warszawie - ostatecznie plan uruchomienia placówki nie wszedł jednak w życie. Mimo to Grzegorzewskiego należy niewątpliwie zaliczyć do grona pierwszych propagatorów tworzenia podstaw współpracy z państwami bałkańskimi, a zwłaszcza nawiązania i utrwalenia bliskich związków z Bułgarią ${ }^{12}$.

Na przełomie XIX i XX w. Grzegorzewskiego zaczęła pochłaniać idea stworzenia ośrodka naukowego do badań nad Wschodem oraz uruchomienia czasopisma naukowego, w którym prezentowane byłyby wyniki prowadzonych badań, analizy oraz korespondencje z szeroko rozumianym Orientem i ziemiami południowo-

literatów lwowskich, Lwów 1898, s. 49; M. Kizilov, Jan Grzegorzewski’s Karaite materials in the archive of the Polish Academy of Sciences in Kraków, „Karaite Archives” 1 (2013), s. 60.

6 J. Reychman, Peleryna..., s. 9-11.

7 O tych podróżach Grzegorzewski kilkakrotnie wspomniał w swoich pracach, m.in. w: Spótczesna Bułgarya, Rok przewrotów (Bułgarya 1885/6) oraz Albania i Albańczycy.

8 J. Grzegorzewski, Spółczesna Bułgarya, „Ateneum” 8 (1883), t. 2, z. 2 i 3.

9 J. Grzegorzewski, Stosunki handlowe z Bułgaryą, „Przegląd Powszechny” 4 (1887), z. 1; J.G.

[J. Grzegorzewski], Szkolnictwo w Bułgaryi, „Przegląd Powszechny” 4 (1887), z. 8, 10, 11.

10 J. Grzegorzewski, Rok przewrotów (Bułgarya 1885/6), Lwów 1900.

11 K. Dobosz, op. cit., s. 178.

12 U. Kaczmarek, Wystawa poświęcona prof. Tadeuszowi S. Grabowskiemu i prof. Janowi Grzegorzewskiemu, Sofia, 24 czerwca 1996, „Etnografia Polska” 41 (1997), z. 1-2, s. 259-261. 
słowiańskimi ${ }^{13}$. Realizacja tego pomysłu już na początku natrafiła jednak na wiele problemów i nie cieszyła się większym zainteresowaniem polskich badaczy, którzy jak m.in. Kazimierz Nitsch - określali Grzegorzewskiego mianem „fantasty i dyletanta"14. W związku z tym postanowił on rozpocząć samodzielne działania. W $1904 \mathrm{r}$. przeniósł się do Sofii, gdzie dwa lata później stworzył Stację Naukową Polską na Wschodzie „Hyacinthaeum”15. Jakkolwiek było to niewątpliwie dużym sukcesem Grzegorzewskiego i ukoronowaniem jego dotychczasowych dokonań naukowych, które już od jakiegoś czasu budziły zainteresowanie w Europie ${ }^{16}$, placówka w Sofii borykała się z poważnymi problemami, przede wszystkim finansowymi. Według niego samego stacja zatrudniała poza nim dwóch pisarzy i adiunkta, posiadała bibliotekę, zbiór rękopisów i numizmatów ${ }^{17}$, ale informacje te uznać można raczej za pobożne życzenia kierownika niż rzeczywistość. Faktem jest bowiem, że kiedy w 1915 r. Grzegorzewski opuszczał Sofię, ciążyły na nim znaczne długi, w tym za czynsz, opał i prąd, a kiedy po zakończeniu I wojny światowej skromna siedziba stacji została otwarta przez władze bułgarskie, znaleziono tylko - jak pisze Zbigniew Klejn - masę rupieci, szmaty, książki i trochę papierów ${ }^{18}$. Niemniej jednak Grzegorzewski podjął w Sofii szerzej zakrojone działania naukowe, a ich owocem były m.in. wydawnictwa źródłowe: $Z$ sydżyllatów rumelijskich epoki wyprawy wiedeńskiej akta tureckie ${ }^{19}$, Dwa fermany suttańskie $z$ XVIII w. Zarys historyczny traktatów handlowych Polski $z$ Turcyą ${ }^{20}$ i Ferman suttana Abdulhamida I $z$ r. $1775^{21}$, a także inne prace, wśród których na uwagę zasługują niewątpliwie: Grób Warneńczyka ${ }^{22}$

${ }^{13}$ K. Dobosz, op. cit., s. 178.

14 Ibidem, s. 179.

15 Głównym celem działania tej placówki miało być gromadzenie, badanie i publikowanie dokumentów archiwalnych związanych z „najbliższym Wschodem”, tj. Bałkanami i Turcją; Stacya naukowa polska na Wschodzie Hyacinthaeum, Warszawa 1916, s. 1; na ten temat także: J. Reychman, O wykorzystanie źródeł orientalnych do historii Polski, „Przegląd Historyczny” 58 (1967), nr 2, s. 297; idem, Peleryna..., s. 40; Z. Klejn, Polskie ślady..., s. 315-316.

${ }^{16}$ Chodzi tu przede wszystkim o opublikowaną w 1903 r. pracę poświęconą dialektowi tatarskiemu w Galicji i językowi karaimskiemu: J. Grzegorzewski, Ein türk-tatarischer Dialekt in Galizien: Vokalharmonie in den entlehnten Wörtern der karaitischen Sprache in Halicz, „Sitzungsberichte der Kaiserlichen Akademie der Wissenschaften Philosophisch-Historische Klasse” 146 (1903), Abh. 1.

17 Stacya naukowa..., s. 4.

18 Z. Klejn, Polskie ślady..., s. 318.

19 J. Grzegorzewski, Z sydżyllatów rumelijskich epoki wyprawy wiedeńskiej akta tureckie, Lwów 1912.

20 J. Grzegorzewski, Dwa fermany sultańskie z XVIII w. Zarys historyczny traktatów handlowych Polski z Turcyą, „Rocznik Orientalistyczny” 1916-1918.

${ }^{21}$ J. Grzegorzewski, Ferman sultana Abdulhamida I z r. 1775, w: Ksiega ku uczczeniu prof. Józefa Tretiaka, Lwów 1913.

22 J. Grzegorzewski, Grób Warneńczyka: badania autentyczności grobu przy 4-tym kilometrze pobojowiska warneńskiego zd. 10-go listopada 1444 r., z 14 załącznikami, Kraków 1911. Warto wspomnieć, że praca ta stała się kanwą ożywionej dyskusji w Akademii Umiejętności w Krakowie, która toczyła się w 1910 r.; M. Hoszowska, op. cit., s. 89-99. 
i wysoko ceniona w świecie naukowym Albania i Albańczycy ${ }^{23}$, a także kilka artykułów zamieszczanych w poczytnych periodykach, w tym w ukazującym się od 1905 r. w Krakowie „Świecie Słowiańskim”24. Po powrocie do Polski Grzegorzewski zajął się głównie badaniami językoznawczymi i folklorystycznymi ${ }^{25}$, ale aż do swojej śmierci w 1922 r. niezmiennie opowiadał się za zacieśnieniem stosunków polsko-bułgarskich ${ }^{26}$.

W swoich pracach publicystycznych poświęconych Bułgarii Jan Grzegorzewski prezentował obraz otaczającej rzeczywistości poprzez pryzmat osobistych zainteresowań, do których należały: historia, kwestie społeczno-polityczne oraz szeroko rozumiana kultura i etnografia. Jednocześnie często dawał w nich upust swoim talentom literackim, wzbogacając narrację licznymi podaniami, legendami i anegdotami, prezentowanymi zazwyczaj w formie specjalnie w tym celu skonstruowanych dialogów, które konfrontował zarówno z wynikami własnych obserwacji i pozyskiwanymi na miejscu informacjami, jak i ówczesną literaturą naukową i pamiętnikarską. Często pojawiały się w nich także fragmenty bułgarskich pieśni ludowych i patriotycznych. W związku $\mathrm{z}$ tym prezentowany przez niego obraz miejscowych stosunków jest bogaty i wieloaspektowy, a autor w swoich rozważaniach przedstawił niemal wszystkie płaszczyzny życia społecznego.

Kto miał sposobność przelotnie przesunąć się przez Byłgaryę w przededniu ostatniej wojny wschodniej, tego dziwny w pierwszej chwili uderzał widok, niezwykły w społeczeństwach naszych; nie spotykało się tam ani żebraków, ani poetów, ani analfabetów. Takim się przedstawia na pierwsze wejrzenie ten naród, który najstarszym może będąc ze Słowian w kulturze chrześcijańskiej, najmłodszym jest na widowni nowoczesnych dziejów politycznych ${ }^{27}$.

Tak pisał Jan Grzegorzewski na początku swojej pracy Spółczesna Bułgarya, trafnie charakteryzując bułgarskie społeczeństwo u progu niepodległości i anonsując te spośród jego cech, które w ciągu zaledwie trzech dziesięcioleci zadecydować miały o tym, że na przełomie XIX i XX w. Bułgaria zdecydowanie górowała nad innymi państwami bałkańskimi pod względem ludnościowym

23 J. Grzegorzewski, Albania i Albańczycy, Lwów 1914.

${ }^{24}$ J. G[rzegorzewski], Echa zjazdu sofijskiego, „Świat Słowiański” 7 (1911), nr 1 (75); idem, Dragan Cankow, ibidem, nr 1 (77); idem, O „Echa zjazdu sofijskiego”, ibidem, nr 1 (78); idem, Stronnictwa bułgarskie za Aleksandra Battenberga, ibidem, nr 2 (80-81); idem, Siedmiomiesięczna walka o samoistność Bułgaryi, ibidem, nr 1 (87); idem, Siedmiomiesięczna walka o samoistność Bułgaryi, „Świat Słowiański” 8 (1912), nr 1 (88); idem, Siedmiomiesięczna walka o samoistność Bułgaryi, ibidem, nr 1 (89); idem, Penczo Sławejkow, ibidem, nr 2 (92-93); idem, Stronnictwa bułgarskie po przewrotach, ibidem, nr 2 (95); idem, Stronnictwa bułgarskie po przewrotach, ibidem, nr 2 (96).

25 J. Grzegorzewski, Jezyk Łach-Karaitów. Narzecze południowe (łucko-halickie), Kraków 1917; idem, Na Spiszu. Studya i teksty folklorystyczne, Lwów 1919. Warto zaznaczyć, że kwestie te interesowały Grzegorzewskiego już wcześniej, o czym świadczyła jego praca: Z kresów Połabskich (Kraków 1885).

26 Z. Klejn, Polskie ślady..., s. 319.

27 J. Grzegorzewski, Spółczesna Bułgarya..., z. 2, s. 201. 
i ekonomicznym, co czyniło ją ważnym i pożądanym partnerem zarówno dla sąsiadów, jak i europejskich mocarstw.

Proces, którego pozytywne efekty Grzegorzewski mógł zaobserwować w 1877 r., miał wówczas już długą historię. Rozpoczął się on bowiem w drugiej połowie XVIII w., wraz ze wzrostem aktywności bułgarskiego społeczeństwa, spowodowanej tzw. bułgarskim odrodzeniem narodowym i pojawieniem się zataczających coraz szersze kręgi idei walki o niezależność kościelną i narodową. Nie ulega wątpliwości, że punktem wyjścia do tych głębokich przemian w mentalności Bułgarów ${ }^{28}$ stały się dwa wydarzenia: 1) ukończenie w 1762 r. przez mnicha z góry Athos Paisija Chilendarskiego, a następnie upowszechnienie działa zatytułowanego Historia słowiano-bułgarska o narodzie i o carach, i o świętych bułgarskich, io wszystkich dziejach $i$ wydarzeniach bułgarskich ${ }^{29}$, opisującego czasy potęgi państwa bułgarskiego ${ }^{30}$; oraz 2) działalność Jurija Wenelina, autora pracy Dawni i dzisiejsi Bułgarzy ${ }^{31}$. Analizując te przemiany, Grzegorzewski wskazał dwa główne obszary, których one dotyczyły. Pierwszym z nich była tzw. kwestia kościelna, głęboko osadzona w idei utworzenia niezależnej Cerkwi bułgarskiej, która w zamysłach jej twórców miała wspierać wysiłki na rzecz krystalizacji i utwierdzania poczucia narodowego ${ }^{32}$.

Po następującym w początkach tureckiego panowania na Bałkanach okresie bezwzględnej walki z chrześcijaństwem, przejawiającej się m.in. w masowym niszczeniu miejsc kultu oraz fiasku prowadzonej później z różnym nasileniem akcji islamizacyjnej ${ }^{33}$, Wysoka Porta pogodziła się z istnieniem i działalnością Cerkwi

28 Odnosząc się do okresu wcześniejszego Grzegorzewski pisał: „Kto sobie przypomni, że Bułgar owych czasów bał się i wstydził przyznać do swojej narodowości, a na zapytanie kim jest, odpowiadał: grekiem [...]”, J. Grzegorzwski, Spółczesna Bułgarya..., z. 2, s. 203.

${ }^{29}$ Kronika, „Świat Słowiański” 8 (1912), nr 1, s. 555-556; История славеноболгарская, Sofija 1961, s. $29-30$.

30 J. Grzegorzewski, Spółczesna Bułgarya..., z. 2, s. 209; W.R. Wegnerowicz, Odrodzenie Bułgaryi, „Literatura i Sztuka. Dodatek do Dziennika Poznańskiego” 48 (1912); S. Zankow, Die Grundlagung der Vefassung der bulgarischen orthodoxen Kirche, Zürich 1917, s. 24-25.

31 J. Grzegorzewski, Spółczesna Bułgarya..., z. 2, s. 202; S.J. Czarnowski, Dziennikarstwo słowiańskie i polskie, Kraków 1895, s. 187. Praca Wenelina Древние и ньюнешние болгаре в политическом, народописном, историческом и религиозном их отношении к россиянам. Историкокритические изыскания została opublikowana w Rosji w dwóch tomach w 1829 i 1841 r., a w 1856 r. ukazało się jej wznowienie.

${ }^{32} \mathrm{Na}$ doniosłość tej kwestii dla sprawy narodowej Grzegorzewski zwrócił uwagę, pisząc: „Bułgaria [...] wtłoczona w obcy jej organizm, odcięta od styczności z pokrewnymi ludami i przylegająca bezpośrednio do centralnego siedliska zaborców, wystawioną została na pierwszy i ciągły krzyżowy ogień wrogich dla niej czynników: tureckiego, greckiego, rumuńskiego i albańskiego; pozbawioną wszelkiego poparcia z zewnątrz, sama się pozbawiła wewnętrznej siły oporu, własnych ożywczych, a pomocniczych do podtrzymania żywotności narodowej źródeł. Taką siłą pomocniczą i takiem źródłem mogło być gorące uczucie religijne i poczucie świadomości w zorganizowanym własnym kościele narodowym”, idem, Spółczesna Bułgarya..., z. 3, s. 540.

${ }^{33} \mathrm{~W}$ ramach tej akcji koncentrowano się początkowo przede wszystkim na zmuszaniu ludności bułgarskiej różnymi sposobami do przyjmowania islamu, ale działania te przyniosły skutki - i to dość ograniczone - jedynie w Rodopach. Wynikało to z przede wszystkim z faktu, że islamiza- 
prawosławnej, czego wymownym wyrazem było stałe zwiększanie zakresu kompetencji miletó $w^{34}$. Z perspektywy Bułgarii zmiany te nie przyniosły jednak przełomu. Przeciwnie, podporządkowanie w drugiej połowie XVIII w. Cerkwi prawosławnej na Bałkanach bezpośrednio patriarchatowi w Konstantynopolu ${ }^{35}$ otworzyło przed Kościołem greckim możliwości szerokiej hellenizacji ziem bułgarskich. Działania w tym obszarze prowadzone były przede wszystkim poprzez obsadzanie zarówno najwyższych urzędów, jak i parafii i klasztorów stanowiących podstawę całej struktury, greckim klerem, bardzo często nieposiadającym odpowiedniego przygotowania teologicznego. Taki stan rzeczy podyktowanym był przede wszystkim faktem, że inwestytura wyższych hierarchów, z patriarchą na czele, wymagała uiszczenia na rzecz władz tureckich odpowiedniej kwoty ${ }^{36}$, a konieczność zapewnienia środków finansowych na ten cel skłaniała do handlowania godnościami i urzędami kościelnymi niższych szczebli. Stąd też stanowiska te najczęściej trafiały w ręce nie tych, którzy byli najlepiej przygotowani do pełnienia posługi duszpasterskiej, ale tych, którzy byli w stanie najwięcej za nie zapłacici ${ }^{37}$. Jednocześnie w znaczący sposób zwiększył się ucisk fiskalny lokalnej ludności ${ }^{38}$, na którą starano się przerzucić koszty tych operacji finansowych. W tym czasie patriarchat konstantynopolitański rozpoczął także prowadzoną na szeroką skalę akcję rugowania języka bułgarskiego z liturgii i przycerkiewnych szkół, tzw. kiliji, co powodowało nie tylko drastyczny spadek poziomu nauczania, ale także upowszechnienie się niezrozumiałego dla Bułgarów języka greckiego w cerkwiach ${ }^{39}$ i wśród części bułgarskiego społeczeństwa,

cja objęła tam słabo uświadomioną ludność pasterską, stojącą na relatywnie niskim poziomie rozwoju społecznego. Jak pisał Grzegorzewski, relacjonując rozmowę z jednym z bułgarskich biskupów, Pomacy „mówiąc po słowiańsku i będąc muzułmanami, zachowują w chatach swoich obrazy Matki Boskiej i Chrystusa, lecz mimo to jeśli nie wyrzucają popów zarówno greckich jak bułgarskich, to okazują dla nich taką samą obojętność, jak dla chodżów muzułmańskich”, ibidem, z. 2, s. 227; a w innym miejscu dodawał: ,ale zresztą zaciętszymi są oni Muzułmanami od Turków i gorzej niż ci nienawidzą chrześcijan”, J. Grzegorzewski, Za Dunajem (Bułgarya, Serbia, Czarnogóra), Lwów 1904, s. 100. W okresie późniejszym władze tureckie zdecydowały się na przesiedlanie na ziemie bułgarskie wyznających islam koczowniczych ludów z Kaukazu i Azji Mniejszej oraz na wsparcie akcji osiedleńczej Tatarów, licząc na ich szybką asymilację z miejscową społecznością. Jednak wysiłki w tym zakresie także nie przyniosły spodziewanych rezultatów; C. Jireček, Geschichte der Bulgaren, Praga 1876, s. 140-142, 146; Bułgarya pod jarzmem tureckim, „Niwa” 16 (1887), z. 302, s. 92-93; A. Bezenšek, Bolgarija in Srbija, Celovec 1897, s. 41.

34 J. Grzegorzewski, Spółczesna Bułgarya..., z. 2, s. 220-221.

35 T. Sława, Propaganda unicka w Bułgaryi, „Świat Słowiański” 9 (1913), nr 2, s. 725.

36 Pod koniec XVI w. opłata za urząd patriarchy wynosiła 6000 dukatów, a w połowie XIX w. osiągnęła już wartość 120000 dukatów; J. Grzegorzewski, Za Dunajem..., s. 91; na ten temat także: C. Jireček, op. cit., s. 511.

37 J. Grzegorzewski, Za Dunajem..., s. 91-93.

38 J. Grzegorzewski, Spółczesna Bułgarya..., z. 2, s. 209.

39 Efektem tych działań była także daleko posunięta marginalizacja niewielkiej grupy duchowieństwa pochodzenia bułgarskiego. Jak pisał Grzegorzewski: „ówcześni księża bułgarscy, jedyni nauczyciele ludu swego byli przez biskupów fanariockich przynaglani do posług kuchennych i stajennych", ibidem, z. 2, s. 206, z. 3, s. 543. 
a zwłaszcza wśród mieszkańców miast ${ }^{40}$. Istotnym następstwem działań hellenizacyjnych była także swego rodzaju dychotomia postaw wyrażająca się z jednej strony postępującym rozdźwiękiem pomiędzy ludnością a Cerkwią prawosławną, areligijnością i daleko posuniętą tolerancją dla innych nurtów światopoglądowych, a z drugiej - przeświadczeniem o niezwykle istotnej roli religii w tworzeniu i utrwalaniu tożsamości narodowej. Jak pisał Grzegorzewski:

Bułgar przywiązany jest do swojej wiary, do swego obrządku, bo jakżeby mogło być inaczej, skoro on jemu w znacznej mierze zawdzięcza zachowanie swojej narodowości od zupełnej zagłady, ale dalekim jest od fanatyzmu i nienawiści dla ludzi innych wyznań; owszem wspólne pod jednym dachem pożycie z różnowiercą nie należy do wyjątków w sferze ludowej, tak samo jak przyjaźń $\mathrm{z}$ osobistościami muzułmańskiemi $[\ldots]^{41}$.

Ta swoista ambiwalencja nie przeszkodziła jednak Bułgarom podjąć walki o uniezależnienie lokalnej Cerkwi od patriarchatu greckiego. W związku z rosnącym niezadowoleniem bułgarskiego społeczeństwa działania na tym polu podjęte zostały w połowie lat 40. XIX w., ale początkowo nie dały one spodziewanych rezultató $w^{42}$. Mimo to przygotowywano się do jej wznowienia, a dogodny moment pojawił się po ogłoszeniu w $1856 \mathrm{r}$. dekretu sułtańskiego znanego pod nazwą hatt-i-humayun, w którym zapowiedziano wprowadzenie tolerancji religijnej i wolności wyznania w Turcji. Zwołany z inicjatywy Wysokiej Porty dwa lat później sobór powszechny ${ }^{43}$, na skutek oporu patriarchy konstantynopolitańskiego, nie zdecydował się jednak zaspokoić bułgarskich żądań, które dotyczyły przede wszystkim kwestii obsadzenia wszystkich lokalnych prowincji kościelnych Bułgarami. Taki stan rzeczy doprowadził do wybuchu powszechnego niezadowolenia, którego szczególne nasilenie przypadło na rok 1860, kiedy podczas nabożeństwa wielkanocnego lider ruchu bułgarskiego Iłarion Makariopolski pominął w modlitwach imię patriarchy konstantynopolitańskiego, manifestacyjnie zrywając związki z patriarchatem ${ }^{44}$. Ponieważ ta jednostronna decyzja poważnie zagroziła stosunkom wewnętrznym w państwie, Wysoka Porta wymogła na patriarchacie zgodę na kontynuowanie pertraktacji w sprawie odrębności bułgarskiej prowincji

${ }^{40}$ Podjęta przez greckie władze kościelne akcja hellenizacyjna przejawiała się także w walce $\mathrm{z}$ bułgarską tradycją historyczną i piśmiennictwem, w ramach której niszczono zabytkowe księgi, manuskrypty, pamiętniki i druki ulotne; ibidem, z. 2, s. 210; J. Grzegorzewski, Za Dunajem..., s. 93.

${ }^{41}$ J. Grzegorzewski, Spótczesna Bułgarya..., z. 2, s. 213; na ten temat także idem, Za Dunajem..., s. 178.

${ }^{42}$ Prowadzili je dwaj wybitni działacze narodowi - późniejszy biskup tyrnowski Iłarion Makariopolski oraz mnich z Góry Athos Neofit Chilendarski-Bozweli; S. Zankow, Die Grundlagung der Vefassung der bulgarischen orthodoxen Kirche, Zürich 1917, s. 27-28. Obaj duchowni zostali uwięzieni, a następnie osadzeni na Górze Athos. W trakcie internowania Neofit zmarł w 1848 r., a Iłarion został zwolniony w $1850 \mathrm{r}$.

43 J. Grzegorzewski, Spółczesna Bułgarya..., z. 2, s. 209.

${ }^{44}$ J. Grzegorzewski, Za Dunajem..., s. 157; S. Zankow, op. cit., s. 27-28. Za ten postępek został on aresztowany przez władze tureckie i w $1861 \mathrm{r}$. zesłany w głąb Turcji, gdzie przebywał do $1864 \mathrm{r}$. 
kościelnej. Choć prowadzono rozmowy na ten temat w latach 1863-1870, ich przebieg wskazywał, że porozumienia nie uda się osiągnąć, zarówno z powodu bezkompromisowej postawy greckich władz kościelnych ${ }^{45}$, jak i nieustępliwości strony bułgarskiej. W tym czasie rosło także niezadowolenie społeczne. Z tego też powodu: „gdy za przykładem biskupa Hilariona [Iłariona] duchowieństwo bułgarskie pod naciskiem ludu wypuszcza podczas publicznego nabożeństwa z modlitw imię patriarchy, kładąc natomiast imię sułtana, gdy parafie bułgarskie wzbraniając się płacić na utrzymanie kleru fanariockiego, który tu i ówdzie poturbowany, opuszcza swoje stanowisko" ${ }^{\prime 6}$, Wysoka Porta, obawiając się przerodzenia się sporu w otwarty konflikt, zdecydowała się interweniować, a 28 lutego $1870 \mathrm{r}$. sułtan Abdülaziz wydał ferman ${ }^{47}$ sankcjonujący odrębność Cerkwi bułgarskiej i powołujący egzarchat ${ }^{48}$.

Jak zauważył Grzegorzewski, w walce o niezależność kościelną niepoślednią rolę odegrała dynamicznie rozwijająca się od połowy XIX w. prasa bułgarska: „naród był podupadły na duchu i przygnębiony, w pierwszej chwili nie mającym świadomości własnych praw, a później nie śmiejący głosu podnieść za sobą, gdy wiedział, że głos ten nie znajdzie posłuchu, gdy wiedział, że inni głos nie podnoszą [...] miano już własną prasę periodyczną, która mogła tę kwestię podnieść publicznie i prowadzić ją drogą jawnej dyskusyi”"49.

Tym samym prasa przejęła na siebie rolę nie tylko czynnika kulturotwórczego, ale przede wszystkim narodowotwórczego. Pierwszym bułgarskim czasopismem było wydawane przez Konstantina Fotinowa w Smyrnie (Izmir) „Lubosłowie”, które ukazywało się w roku 1842, a następnie w latach $1844-1846^{50}$. Czasopismo

45 T. Sława, op. cit., s. 726.

46 J. Grzegorzewski, Spółczesna Bułgarya..., z. 2, s. 209; na ten temat także: J. Hołubowicz, Bułgarya, jej przeszłość dziejowa i jej obecne narodowe i religijne odrodzenie, Kraków 1885, s. 61; Kronika, „Świat Słowiański” 7 (1911), nr 1, s. 403.

47 Tekst dokumentu w: J. Rubacha, A. Malinowski, A. Giza, Historia Bułgarii 1870-1915. Materiały źródłowe z komentarzami, Warszawa 2004, s. 15-17.

48 J. Grzegorzewski, Spółczesna Bułgarya..., z. 2, s. 209; C. Jireček, op. cit., s. 236; Bułgarya pod jarzmem..., z. 302, s. 945; C. Jankowski, Na gruzach Turcji. Zarysy polityczno-publicystyczne, Warszawa 1915, s. 46; A. Miecznik, Macedonja i Macedończycy, Warszawa 1904, s. 98; S.J. Czarnowski, op. cit., s. 190. Warto także dodać, że spór trwał jednak dalej, co doprowadziło do obłożenia 14 IX 1872 r. Egzarchatu przez patriarchę konstantynopolitańskiego ekskomuniką (J. Grzegorzewski, Spółczesna Bułgarya..., z. 2, s. 213), która została zniesiona dopiero w 1909 r.; na ten temat także: T. Sława, op. cit., s. 728; C. Jireček, op. cit., s. 236. Warto również podkreślić, że powstanie Egzarchatu miało pośredni wpływ na przekształcenie się toczonego do tej pory niemal wyłącznie na niwie kościelnej sporu w głęboki zatarg natury politycznej, który zwłaszcza po 1878 r. wpływał na stosunki bułgarsko-greckie i zaostrzał toczoną przez oba państwa walkę o strefy wpływów w Macedonii, trwającą nieprzerwanie niemal do wybuchu wojen bałkańskich w $1912 \mathrm{r}$.

49 J. Grzegorzewski, Spółczesna Bułgarya..., z. 2, s. 210.

50 Ibidem, s. 211; idem, Za Dunajem..., s. 155: Kronika, „Świat Słowiański” 7 (1911), nr 1, s. 80: W.R. Wegnerowicz, op. cit.; S.J. Czarnowski, op. cit., s. 187-188. 
to posiadało charakter encyklopedyczny, było bogato ilustrowane i zamieszczało artykuły na temat historii, języka bułgarskiego i geografii oraz teksty moralizatorskie. Głównym celem, jaki stawiali sobie jego twórcy, było w pierwszym rzędzie podniesienie świadomości Bułgarów i krzewienie ducha narodowego. W tym czasie ukazywało się w Lipsku czasopismo „Byłgarski Oreł” redagowane przez Iwana Bogorowa, które jednak, zaledwie po wydaniu kilku numerów, zostało zamknięte w 1847 r. Nie zraziło to redaktora i dwa lata później założył on w Konstantynopolu kolejne pismo polityczno-literackie - „Carigradski Westnik”51, ukazujące się nieprzerwanie przez trzynaście lat. Obok esejów publicystycznych publikowano w nim artykuły z zakresu geografii i historii, biografie znanych postaci oraz teksty literackie. Na łamach tego czasopisma debiutowali m.in. poeta i kompozytor Dobri Czintułow oraz poeta, folklorysta, działacz polityczny i późniejszy minister Petko Sławejkow, a publicyści czasopisma brali aktywny udział w dyskusjach, które toczyły się na początku lat 60 . XIX w. pomiędzy zwolennikami a przeciwnikami zawarcia unii kościelnej z Rzymem. Środowisko to zdecydowanie odrzucało ideę zbliżenia z Kościołem katolickim, propagowaną w tym czasie przez Dragana Cankowa i grupę skupioną wokół założonego przez niego w 1859 r. czasopisma „Byłgarija” ${ }^{52}$.

Jak wspomniano, niepoślednią rolę odegrała prasa w okresie walki o uniezależnienie Cerkwi bułgarskiej od zwierzchnictwa patriarchatu greckiego. W tym czasie znacząco wzrosła liczba czasopism. W latach 1858-1862 w Konstantynopolu ukazywały się, cieszące się dużą popularnością, „Byłgarski Kniżnici” pod redakcją początkowo Dimityra Mutewa, a następnie m.in. I. Bogorowa, Gawriła Krestowicza i Todora Burmowa ${ }^{53}$. Czasopismo to, będące organem działającej w tureckiej stolicy Czytelni Bułgarskiej ${ }^{54}$, podejmowało przede wszystkim tematykę historyczną, społeczną i polityczną, a szczególnym uznaniem czytelników cieszyły się teksty poświęcone kwestiom kościelnym i artykuły z zakresu słowianoznawstwa, językoznawstwa oraz szeroko rozumianej edukacji. W toczącym się sporze istotną rolę odgrywała także ukazująca się od 1862 r. gazeta „Turcija” wydawana przez Nikołę Genowicza $^{55}$, a także aktywnie działająca na polu krzewienia idei narodowej prasa emigracyjna. W 1860 r. bułgarscy studenci skupieni wokół Konstantina Miladinowa założyli w Moskwie gazetę „Bratski Trud”56, którą redagował Rajko Żinzifow. W tym czasie Georgi Rakowski wydawał najpierw w Belgradzie czasopismo

${ }^{51}$ J. Grzegorzewski, Spółczesna Bułgarya..., z. 2, s. 211; W.R. Wegnerowicz, op. cit.

52 J. Grzegorzewski, Spółczesna Bułgarya..., z. 2, s. 211; Kronika, „Świat Słowiański” 7 (1911), nr 1, s. 80; S.J. Czarnowski, op. cit., s. 188.

53 J. Grzegorzewski, Spółczesna Bułgarya..., z. 2, s. 211; S.J. Czarnowski, op. cit., s. 188.

54 T. Sopodźko, O czasopismach w Bułgaryi, „Przegląd Powszechny” 8 (1891), nr 29, s. 436. Czytelnia Bułgarska odgrywała $\mathrm{w}$ tym czasie bardzo ważną rolę w życiu bułgarskiej diaspory w Konstantynopolu, prowadząc działalność oświatową i edukacyjną. Poza udostępnianiem bułgarskojęzycznej prasy ukazującej się na terenie Turcji, zajmowała się także działalnością wydawniczą i popularyzatorską oraz teatralną i dobroczynną.

55 S.J. Czarnowski, op. cit., s. 188-189; J. Grzegorzewski, Spółczesna Bułgarya..., z. 2, s. 211.

56 J. Grzegorzewski, Spółczesna Bułgarya..., z. 2, s. 211; S.J. Czarnowski, op. cit., s. 188. 
„Dunawski Lebed”57, a od 1864 r. w Bukareszcie gazetę „Bydesztnost”. Dużą popularnością cieszyły się także wychodzące w tym czasie w Rumunii pisma: Lubena Karawełowa „Swoboda”, Iwana Kasabowa „Narodnost” i „Nezawisimost”, konserwatywny dziennik "Otczestwo” oraz założone w Konstantynopolu przez Petka Sławejkowa pismo „Gajda” i czasopismo polityczno-satyryczne „Makedonija”, poświęcone przede wszystkim sprawom Bułgarów macedońskich ${ }^{58}$, a także wydawana staraniem Amerykańskiego Towarzystwa Biblijnego ${ }^{59}$ początkowo jako miesięcznik, a następnie jako tygodnik - „Zornica”, w której swoje teksty publikowali wszyscy najwięksi działacze ruchu narodowego, oraz kilka innych ${ }^{60}$.

W kontekście toczącej się walki o niezależność kościelną nie sposób pominąć zaprezentowaną przez Grzegorzewskiego ${ }^{61}$ i wspomnianą powyżej, lansowaną przez część bułgarskich kręgów politycznych ideę uniezależnienia Cerkwi bułgarskiej od zwierzchności patriarchy konstantynopolitańskiego poprzez przekształcenie jej w Cerkiew greckokatolicką i podporządkowanie papieżowi.

Manifestacyjne zerwanie więzów łączących Cerkiew bułgarską z patriarchatem konstantynopolitańskim w 1860 r. oraz bierna postawa Wysokiej Porty wobec przybierającego na sile konfliktu skłoniły pod koniec grudnia 1860 r. część przebywających $\mathrm{w}$ tureckiej stolicy bułgarskich środowisk politycznych do nawiązania kontaktów z tamtejszym legatem papieskim abpem Paulusem Brunonim ${ }^{62}$. Ponieważ zaprezentowana przez Bułgarów wizja stworzenia Cerkwi greckokatolickiej okazała się zbieżna $\mathrm{z}$ watykańską racją stanu, wkrótce potem do Rzymu udała się specjalna bułgarska delegacja, z Draganem Cankowem na czele, która przekazała Piusowi IX prośbę o stworzenie na terenie Bułgarii katolickiej prowincji kościelnej, kontynuującej tradycje obrządku bizantyjskiego i posługującej się w liturgii językiem starobułgarskim ${ }^{63}$. Efektem tej wizyty było erygowanie 21 stycznia 1861 r. bułgarskiego Kościoła katolickiego (unickiego), a następnie, w połowie kwietnia, konsekrowanie pierwszego jego zwierzchnika - abpa Józefa

57 J. Grzegorzewski, Spółczesna Bułgarya..., z. 2, s. 211.

58 Jak pisał Grzegorzewski, było to czasopismo: „redagowane z niepospolitym talentem i w znacznej mierze poświęcone sprawie Bułgarów macedońskich; w tym też celu redakcya stosując się do nawyknień tamtejszej ludności zamieszczała nawet artykuły w języku greckim lub w narzeczu macedońskim czcionkami greckiemi”, ibidem, z. 2, s. 211-212.

59 R.J. More, Under the Balkans. Notes of a Visit to the District of Philippopolis in 1876 - Primary Source Edition, London 1877, s. 41-43.

${ }^{60}$ J. Grzegorzewski, Spółczesna Bułgarya..., z. 2, s. 211, Kronika, „Świat Słowiański” 7 (1911), nr 1, s. 80, S.J. Czarnowski, op. cit., s. 189-190. Zasługi na polu umacniania ducha narodowego miały także czasopisma tworzone w latach 70. XIX w., spośród których Grzegorzewski wymienił wydawane: w Konstantynopolu - „Napredyk”, „Wek” i „Den”, w Adrianopolu - „Odrin”, w Ruse „Dunaw” oraz w Bukareszcie - „Znamie”, „Nezawisimost” i „Swoboda”, J. Grzegorzewski, Spółczesna Bułgarya..., z. 2, s. 211-212, przyp. 2.

${ }^{61}$ J. Grzegorzewski, Spótczesna Bułgarya..., z. 2, s. 213; idem, Dragan Cankow, „Świat Słowiański” 7 (1911), nr 1, s. 356-357; idem, Za Dunajem..., s. 157-158.

62 J. Hołubowicz, op. cit., s. 61.

63 J. Grzegorzewski, Za Dunajem..., s. 158. 
Sokolskiego ${ }^{64}$. Tymczasem idea stworzenia niezależnej bułgarskiej prowincji pod zwierzchnictwem Rzymu spotkała się nie tylko z wrogim przyjęciem patriarchatu konstantynopolitańskiego, który podjął u władz tureckich pospieszne działania na rzecz unicestwienia tych planów, co znacząco zaostrzyło toczący się wcześniej spór, ale także wywołała duże zamieszanie $\mathrm{w}$ bułgarskim ruchu narodowym, na kilka miesięcy pogrążając jego członków w zaciętych dyskusjach ${ }^{65}$. Spory te nieco przycichły dopiero po zaginięciu w niewyjaśnionych okolicznościach 18 czerwca 1861 r. abpa Sokolskiego, o co nieoficjalnie oskarżano zarówno Greków, jak i wrogo ustosunkowanych do idei unickiej Rosjan ${ }^{66}$.

$\mathrm{W}$ związku z tym bułgarską prowincję podporządkowano legatowi papieskiemu w Konstantynopolu, co zaważyło na bardzo wolnym tempie tworzenia jej struktur. Starając się przyspieszyć ten proces, podjęto w Rzymie decyzję o przekazaniu prac w ręce - rekrutującego się głównie spośród Polaków - Zgromadzenia Zmartwychwstania Pana Naszego Jezusa Chrystusa, którego członków zwano potocznie zmartwychwstańcami. Dlatego w 1863 r. do Adrianopola przybył Karol Kaczanowski, a dzięki jego wysiłkom w krótkim czasie powstała kaplica i szkoła, które stanowić miały bazę do dalszej rozbudowy struktur kościelnych ${ }^{67}$. W tym czasie w Płowdiwie utworzono także drugą placówkę oświatową ${ }^{68}$. Mimo dużego zaangażowania wyniki prowadzonych przez zmartwychwstańców prac, były bardzo skromne. W 1865 r. liczbę członków Kościoła w wilajecie adrianopolskim oceniano na ok. 700 osób, a obie szkoły kształciły zaledwie kilkudziesięciu uczniów ${ }^{69}$. Sytuacja ta nieznacznie zmieniła się po konsekrowaniu w tym roku nowego zwierzchnika Cerkwi unickiej - bpa Rafała Popowa, ale wzrost liczby jej członków postępował wolno ${ }^{70}$. Przyczyną takiego stanu rzeczy był niewątpliwie fakt, że - jak słusznie zauważył ks. Józef Hołubowicz - idea unii z Rzymem „bardziej z politycznych niż religijnych wyrosła pobudek"71. Dlatego w miarę zaostrzania się sporu

${ }^{64}$ Ibidem, s. 158; T. Sława, op. cit., s. 727; Bułgarya pod jarzmem..., z. 302, s. 97. Bułgarski kościół unicki został zatwierdzony przez Wysoką Portę 9 VI 1861 r.

65 J. Grzegorzewski, Dragan Cankow..., s. 357; Butgarya pod jarzmem..., z. 302, s. 97-98; J. Hołubowicz, op. cit., s. 69.

${ }^{66}$ J. Grzegorzewski, Za Dunajem..., s. 159; T. Sława, op. cit., s. 727; Bułgarya pod jarzmem..., z. 302, s. 98; J. Hołubowicz, op. cit., s. 67-68. Na ten temat zob. także: В. Каравълчев, Холмската мисия на Йосиф Соколски и краят на Брест-литовската уния, „Християнство и култура” 9 (2011), s. 134-142, В. Каравълчев В, Холмската мисия на Йосиф Соколски и краят на Брест-литовската уния, „Християнство и култура” 7 (2011), s. 124-131.

67 J. Grzegorzewski, Za Dunajem..., s. 160; Z. Klejn, Polskie ślady..., s. 291.

${ }_{68}$ Przegląd prasy słowiańskiej, „Świat Słowiański” 7 (1911), nr 1, s. 145-146.

69 J. Hołubowicz, op. cit., s. 72-73, 74. Zdecydowanie lepsze wyniki dawały działania podjęte na terenie Macedonii, prowadzone przez Zgromadzenie Misyjne, tzw. lazarystów. W 1863 r. Kościół unicki w okolicach Monastiru skupiał ok. 20 wsi i 2000 osób.

${ }^{70}$ Pod koniec lat 70. XIX w. liczbę unitów szacowano na ok. 14 tys. w Bułgarii i Tracji oraz ok. 17 tys. w Macedonii; T. Sława, op. cit., s. 727.

${ }^{71}$ J. Hołubowicz, op. cit., s. 79; na ten temat także: T. Sława, op. cit., s. 726; J. Hołubowicz, op. cit., s. 227. 
z patriarchatem oddziaływanie ideologii unickiej znacząco spadało, a po reaktywacji państwa bułgarskiego, w którym dominującym wyznaniem na mocy konstytucji tyrnowskiej stało się prawosławie ${ }^{72}$, miało wyłącznie marginalne znaczenie.

Utworzenie w 1870 r. egzarchatu bułgarskiego miało bezpośredni wpływ na drugi wskazany przez Grzegorzewskiego obszar głębokich przemian bułgarskiej świadomości, wpływających pośrednio także na inne, obok kształtowania poczucia tożsamości narodowej, sfery życia społecznego. Obszarem tym było szkolnictwo, którego rozwój powiązać należy z wykrystalizowaniem się idei odrodzenia narodowego ${ }^{73}$.

Przeprowadzone w drugiej połowie XVIII w. zmiany w administracji kościelnej i postępująca hellenizacja ziem bułgarskich zaczęły z upływem czasu budzić coraz większy sprzeciw Bułgarów, sceptycznie nastawionych do idei zastępowania języka bułgarskiego greckim, nie tylko w cerkwiach, ale także w nielicznych miejskich i wiejskich szkołach przycerkiewnych ${ }^{74}$. Ten oddolny bierny opór od końca drugiej dekady XIX w. zaczęła wspierać zamieszkująca południowe tereny Rosji bułgarska emigracja, która, korzystając z przychylności władz rosyjskich, masowo kształciła się w tworzonych dla niej placówkach oświatowych. Instytucje te nie tylko krzewiły ducha narodowego, ale przede wszystkim uczyły języka bułgarskiego ${ }^{75}$, a ich absolwenci, inspirowani działalnością Jurija Wenelina ${ }^{76}$, coraz częściej wysuwali ideę tworzenia podobnych placówek na terenie Bułgarii. Z ich inicjatywy już w 1835 r. w Gabrowie powstała pierwsza szkoła bułgarska ${ }^{77}$, a w latach następnych - sieć niewielkich placówek oświatowych niezależnych od patriarchatu greckiego ${ }^{78}$. Równocześnie pojawiały się drukowane w Rosji, Rumunii, Austrii i Serbii bułgarskie

72 C. Jireček, op. cit., s. 236.

${ }^{73}$ Procesy te przenikały się wzajemnie tak głęboko, że - jak pisał Grzegorzewski - „Można powiedzieć, że dzieje odrodzenia narodowości bułgarskiej w XIX w. - to dzieje jej szkolnictwa”, J.G. [J. Grzegorzewski], Szkolnictwo..., z. 8, s. 306.

${ }^{74}$ Warto podkreślić, że opór ten zdecydowanie większe rozmiary przybrał na wsi, a jak napisał ks. J. Hołubowicz, to właśnie lud wiejski, „lubo najwięcej uciskany i gnębiony, cierpliwością pokonał zawziętość nieprzyjaciół i uratował mowę ojczystą i główne podstawy życia narodowego", J. Hołubowicz, op. cit., s. 58.

75 Ibidem, s. 59.

${ }^{76}$ Jak słusznie zauważył Grzegorzewski, praca Wenalina Dawni i dzisiejsi Bułgarzy i jego poglądy „pozyskały mu wziętość i zapewniły rozgłos z tej i tamtej strony Dunaju, lecz wpływ poruszonej przez niego idei odrodzenia narodowego na umysły spółczesnych, wpływ tem donioślejszy, że się przejawił w natychmiastowej bezpośredniej działalności praktycznej, uchwytnej, dotykalnej, dającej się cyframi obliczyć”, J. Grzegorzewski, Spółczesna Bułgarya..., z. 2, s. 203; na ten temat także: idem, Za Dunajem..., s. 155.

77 J. Grzegorzewski, Spótczesna Bułgarya..., z. 2, s. 203; J.G. [J. Grzegorzewski], Szkolnictwo..., z. 8, s. 306.

78 J. Grzegorzewski, Spółczesna Bułgarya..., z. 2, s. 204; idem, Za Dunajem..., s. 155. Zakładanie tych szkół było możliwe dzięki biernej postawie władz tureckich, które nie interesowały się bułgarskim szkolnictwem. „Można było zakładać szkoły, byle tylko budynki owych nie manifestowały się na zewnątrz demonstracyjnie, jako przybytki nauki niewiernych, tak samo jak przybytki kultu religijnego", J.G. [J. Grzegorzewski], Szkolnictwo..., z. 8, s. 306-307. 
książki, które stanowiły podstawowe materiały dydaktyczne ${ }^{79}$. Początkowo wprawdzie proces ten postępował wolno, ale pod koniec lat 50. XIX w. uległ on znacznemu przyspieszeniu na skutek napływu środków finansowych przekazywanych przez środowiska emigracyjne i zagraniczne organizacje dobroczynne, głównie rosyjskie. Jednocześnie starano się pozyskać do współpracy lokalną społeczność, którą zachęcano do asygnowania własnych środków na utrzymywanie placówek oświatowych ${ }^{80}$. Dzięki temu możliwe stało się wówczas podjęcie działań na rzecz podniesienia szkół w Gabrowie i Płowdiwie do rangi sześcioklasowych szkół realnych ${ }^{81}$ oraz zwiększenia liczby placówek oświatowych szczebla podstawowego ${ }^{82}$, nad którymi opiekę roztoczył egzarchat bułgarski. W tym czasie dokonano także ujednolicenia programów nauczania, aby bułgarskie szkoły były w stanie we właściwy sposób przygotowywać kandydatów do podjęcia studiów na zagranicznych uczelniach wyższych. Dlatego mimo trudności liczba bułgarskich szkół stale rosła i już w połowie lat 70. XIX w. placówki oświatowe posiadała większość bułgarskich miejscowości. Efekty tego procesu opisywał Jan Grzgorzewski następująco: „Przejeżdżając przez wioskę bułgarską [...] podróżnik nie potrzebował się pytać mieszkańców: czy macie szkołę, czy uczniowie uczęszczają do niej, lecz wiele macie szkół, ilu uczniów uczęszcza do nich, bo po drodze waszej prawie nie było wioszczyny, któraby była pozbawiona szkoły; niech się ona składa bodaj z 50 chat, budynek szkolny jest już koniecznym" ${ }^{83}$. Dlatego odsetek analfabetów bułgarskim społeczeństwie szybko malał, a dostęp do literatury i prasy w znaczący sposób poszerzał horyzonty i wpływał na poziom świadomości narodowej ${ }^{84}$.

Prace zapoczątkowane przed odzyskaniem niepodległości zyskały jeszcze większy wymiar po $1878 \mathrm{r}$. W okresie funkcjonowania tymczasowej administracji

79 C. Jireček, op. cit., s. 243.

${ }^{80}$ Jak pisał Grzegorzewski: „Będąc obojętnym, rząd padyszacha nic nie łożył na szkoły bułgarskie; cały ciężar o ich pieczę spoczywał na barkach samego społeczeństwa - na barkach każdej gminy", J.G. [J. Grzegorzewski], Szkolnictwo..., z. 8, s. 307.

${ }^{81} \mathrm{~W}$ okresie późniejszym podobne placówki powstały także w innych miejscowościach. W szkołach tych uczono języka bułgarskiego, historii, arytmetyki i algebry, geometrii, przyrody, retoryki i języka obcego - najczęściej tureckiego, francuskiego lub niemieckiego, oraz języka starobułgarskiego; R.J. More, op. cit., s. 29-30.

82 W szkołach tych uczono czytania i pisania oraz podstaw arytmetyki, a nauka trwała jeden rok po sześć godzin dziennie. Koszty utrzymania szkoły i pensji nauczyciela, która wynosiła 1000-1500 piastrów tureckich lub równowartość tej kwoty w zbożu, ponosiła gmina; ibidem, s. 28.

${ }^{83}$ J. Grzegorzewski, Spółczesna Bułgarya..., z. 2, s. 204; na ten temat także: Р. Манафова, Културното развитие на България при временното руско управление (1877-1879), w: Известия на Института за история, т. 29: Из историята на българската наука, просвета и култура през XIX и XX в., 1986, s. 289.

${ }^{84}$ Dokonania Bułgarów w walce $\mathrm{z}$ analfabetyzmem budziły powszechne uznanie nie tylko $\mathrm{w}$ regionie, ale w całej Europie. Pod koniec XIX w. odsetek ludzi niepiśmiennych wynosił bowiem średnio ok. 45\%, podczas gdy w Czrnogórze - 94\%, Serbii - 75\%, w Chorwacji - 67\% (Kronika, „Świat Słowiański” 9 [1913], nr 1, s. 194), a na ziemiach polskich, w Galicji i Królestwie Polskim - ponad $80 \%$. 
rosyjskiej podjęto działania na rzecz możliwie najszybszego uruchomienia tych placówek oświatowych, które zostały zamknięte podczas działań wojennych. Zdecydowano się również nadać spontanicznie do tej pory prowadzonej rozbudowy sieci szkolnictwa bardziej zorganizowaną i planową formę. Pracami tymi kierował Marin Drinow, a na ich efekty nie trzeba było długo czekać. Na przełomie 1878 i 1879 r. na terenie Księstwa Bułgarii działało 1088 szkół ludowych, w których naukę pobierało niemal 48,5 tys. uczniów ${ }^{85}$. Jednocześnie bułgarskie kręgi polityczne dołożyły starań, aby kwestie oświatowe zyskały poczesne miejsce w aktach prawnych regulujących życie społeczne, z ustawą zasadniczą na czele. Stąd też w art. 78 konstytucji tyrnowskiej znalazł się zapis wprowadzający w Bułgarii powszechne, bezpłatne i obowiązkowe kształcenie podstawowe ${ }^{86}$. Nadzorem nad wprowadzaniem w życie zapisów konstytucyjnych zajęło się Ministerstwo Oświecenia Publicznego na szczeblu centralnym i utworzone wówczas inspektoraty szkolne w terenie. Stojący na czele tych ostatnich urzędnicy, zwłaszcza w pierwszych latach po odzyskaniu niepodległości, borykali się często z poważnymi problemami, wynikającymi przede wszystkim z ówczesnej kondycji finansowej państwa ${ }^{87}$. Zdawano sobie jednak sprawę z roli, jaką oświata miała odgrywać w życiu społecznym. Dobitnie świadczą o tym słowa Grzegorzewskiego: „Od szkoły elementarnej wymaga się nie tylko prostego nauczania, ale i wychowania dzieci. Wykład i dyscyplina mają budzić u dziatwy poczucie honoru, miłości dla ojczyzny i zamiłowanie do pracy, ma ją nauczyć ochędostwa, porządku i przyzwoitego zachowania się"88. Dlatego, mimo trudności, liczba placówek oświatowych wzrosła w $1881 \mathrm{r}$. do 1365 . Poważny problem stanowił także brak nauczycieli, którzy po odzyskaniu niepodległości szukali lepiej płatnych posad w strukturach państwowych ${ }^{89}$. Ponieważ sytuacja ta groziła całkowitym paraliżem systemu szkolnego, zdecydowano się znacząco uprościć proces kształcenia pedagogicznego, a ofertę skierowano przede wszystkim do ludzi młodych, którzy zobowiązani byli jedynie do ukończenia 6-8-tygodniowego kursu przygotowującego do pracy w szkole ${ }^{90}$. Jakkolwiek działania te

${ }^{85}$ C. Jireček, op. cit., s. 247. W tym czasie w Rumelii Wschodniej działało 846 bułgarskich szkół ludowych, do których uczęszczało ponad 48 tys. uczniów, oraz 17 realnych, w których uczyło się ok. 2 tys. dzieci. Sprawy edukacji w tej prowincji podlegały dyrekcji oświecenia publicznego przy generalnym gubernatorze, a nadzór w terenie sprawowało 50 inspektorów - po jednym na każdy okręg szkolny; J.G. [J. Grzegorzewski], Szkolnictwo..., z. 10, s. 170, 171; Z. Przesmycki, Rumelia Wschodnia, „Ateneum” 10 (1885), nr 4, s. 259-260.

86 J.G. [J. Grzegorzewski], Szkolnictwo..., z. 8, s. 307, 309.

87 Jak pisał Grzegorzewski: „stanowisko takiego inspektora było jednym z najpoważniejszych i najtrudniejszych, $\mathrm{z}$ którem nie da się porównać stanowiska podobnego inspektora $\mathrm{w}$ żadnym innym kraju i ocenić go należycie można tylko przez znajomość tego wyjątkowego stanu, w jakim się znajdować musiała szkoła w nowopowstającym państwie, gdzie wszystko trzeba było tworzyć począwszy od książek i ławek, a skończywszy na funduszach i personelu nauczycielskim”, ibidem, s. 308.

${ }^{88}$ Ibidem, z. 10, s. 174.

89 Ibidem, s. 172.

90 Ibidem, s. 173. Podobne kursy organizowano także w Rumelii Wschodniej. 
w znaczący sposób obniżyły poziom wykształcenia nauczycieli, to jednak pozwoliły zwiększyć ich liczbę z 1379 w 1879 r. do 1760 dwa lata później ${ }^{91}$. Równocześnie podjęto próby pozyskania pedagogów za granicą oraz uruchomiono program stypendialny, w ramach którego wysyłano najlepszych uczniów na studia na różnych wyższych uczelniach w Europie ${ }^{92}$. Jednocześnie władze bułgarskie starały się odpowiednio korelować potrzeby finansowe z możliwościami państwa. Aby odciążyć skromny w tym czasie budżet utrzymano utrwaloną jeszcze $\mathrm{w}$ czasach okupacji tureckiej zasadę finansowania i utrzymywania szkół przez gminy. Zgodnie $\mathrm{z}$ rozporządzeniami to gminy miały asygnować środki na przygotowanie, wyposażenie i utrzymanie budynku szkolnego oraz opłacenie nauczyciela, a - jak pisał Grzegorzewski - „państwo pozostawia sobie jeno kontrolę i przychodzi z pomocą - że tak powiem - duchową przez przysposobienie nauczycieli oraz dostarczanie niezbędnych środków naukowych, jak np. układanie podręcznych książek etc." ${ }^{\prime 93}$. Fundusze gminne przeznaczone na oświatę pochodziły z dwóch źródeł. Pierwszym z nich były obowiązkowe składki z wpłacane przez każdego z mieszkańców, a drugim $-2 / 3$ dochodów ze sprzedaży świec nabywanych w cerkwiach. Budżet ten okazjonalnie zasilały prywatne datki $\mathrm{w}$ pieniądzu lub $\mathrm{w}$ naturze, $\mathrm{np}$. $\mathrm{w}$ zbożu lub winie, oraz zapisy testamentowe, w których na rzecz szkoły przekazywano najczęściej środki finansowe, ale niejednokrotnie także nieruchomości. Czasami zdarzało się także, że instytucje oświatowe otrzymywały prawo czerpania zysków z nadziałów ziemi z majątku państwowego, użyczanych przez osoby prywatne lub terenów wskazanych przez gminy. Stąd też w niektórych gminach dysponowały one areałem znacznie przekraczającym 50 ha, składającym się z pól uprawnych, pastwisk i lasów oraz "zaopatrzonym” w karczmy, kramy, młyny, piekarnie itp. ${ }^{94}$

$\mathrm{W}$ strukturze bułgarskiego szkolnictwa $\mathrm{w}$ pierwszych latach po odzyskaniu niepodległości wydzielano trzy grupy. Pierwszą z nich i najbardziej liczną tworzyły elementarne szkoły gminne, nauczające w oparciu o jednolity, ustalony przez państwo program nauczania ${ }^{95}$; nauka w nich była bezpłatna ${ }^{96}$. Drugą - szkoły

${ }^{91}$ C. Jireček, op. cit., s. 247. Jednocześnie podjęto działania na rzecz stworzenia podstaw szkolnictwa pedagogicznego. „Czteroklasowe szkoły zamieniono na seminarya nauczycielskie. W 1880/81 otwarto w Szumli [Szumen] czasowy kurs pedagogiczny, a w następnym roku stały, w którym nauka trwała 1 rok; drugi taki kurs otwarto we Wracy", J.G. [J. Grzegorzewski], Szkolnictwo..., z. 10, s. 173.

92 Ibidem, z. 11, s. 333-334. Celem tego programu było kształcenie nie tylko nauczycieli, ale także innych specjalistów: lekarzy, architektów, artystów itp.

93 Ibidem, z. 8, s. 310. Warto jednak zaznaczyć, że ubogie gminy mogły liczyć na wsparcie państwa. Pomoc ta polegała zarówno na przekazywaniu z majątku państwowego budynków lub materiałów potrzebnych do ich budowy, jak i na pożyczkach i subwencjach na wyposażenie i pomoce szkolne.

94 J.G. [J. Grzegorzewski], Szkolnictwo..., z. 8, s. 311-312.

95 Tę grupę uzupełniały gminne szkoły realne, dwu-, trzy-, a nawet pięcioklasowe, które pozostawały na utrzymaniu gminy, ale charakteryzowały się różnymi, dostosowanymi do lokalnych potrzeb i możliwości finansowych, programami nauczania; ibidem, s. 309.

${ }^{96}$ Kształcenie elementarne trwało cztery lata, po 25 godzin tygodniowo i obejmowało naukę religii, języka bułgarskiego, podstaw przyrody, geografii i historii ojczystej, rachunków, rysowania, śpiewu oraz gimnastykę. 
prywatne, częściej spotykane w Rumelii Wschodniej, otwierane staraniem mniejszości narodowych: Żydów, Turków, Greków czy Ormian, oraz szkoły fundowane przez innowierców, takie jak gimnazja katolickie w Płowdiwie i Adrianopolu czy szkoły protestanckie w Samkowie i Płowdiwie. Trzecią grupę stanowiły szkoły państwowe, czyli szkoły średnie (gimnazja) i szkoły specjalne (techniczne, rolnicze i seminaria duchowne). Szkół tego typu było przed 1877 r. na ziemiach bułgarskich tylko trzy, ale w ciągu zaledwie pięciu lat ich liczba wzrosła do $13 \mathrm{w}$ Księstwie Bułgarii i 32 w Rumelii Wschodniej ${ }^{97}$.

Istotnym elementem polityki oświatowej $\mathrm{w}$ tym okresie były podejmowane próby egzekwowania obowiązku szkolnego. Mimo że społeczeństwo bułgarskie en masse dostrzegało korzyści płynące $\mathrm{z}$ nauki ${ }^{98} \mathrm{i}$ chętnie wspierało rozwój oświaty, zdarzały się także wyjątki od tej reguły. Przykład takiego zachowania zaprezentował Grzegorzewski, pisząc: „W pewnej wiosce powiatu kostendylskiego [kiustenditskiego], gdy inspektor otworzył nową szkołę, włościanie poukrywali swoje dzieci po chałupach, a matki tych, których w końcu zaprowadzono do szkoły, rwały sobie włosy na głowie i przeklinały sprawców otwarcia szkoły"99. Jakkolwiek tego typu przypadki zdarzały się sporadycznie, średnia frekwencja w szkołach wahała się od 50 do $70 \%$ i wprowadzenie "przymusu” szkolnego wydawało się w pełni uzasadnione. Tu jednak władze państwowe zmuszone były uwzględniać miejscowe zwyczaje i specyfikę regionu. Dlatego akceptowano różną długość roku szkolnego w szkołach miejskich i wiejskich ${ }^{100}$, a kary za naruszenie przepisów nie były zbyt dotkliwe i wymierzano je stosunkowo rzadko ${ }^{101}$.

Nie ulega wątpliwości, że niezwykła konsekwencja, jaką wykazali Bułgarzy na polu walki o niezależną Cerkiew i w obszarze rozwoju szkolnictwa przyniosła rezultaty daleko większe od spodziewanych i niespotykane w innych częściach Europy. W ciągu stosunkowo krótkiego czasu udało się wydobyć bułgarskie społeczeństwo z niemal zupełnej politycznej apatii, ugruntować w nim ducha narodowego i wpoić miłość do ojczyzny, którą wielokrotnie manifestowało w okresie późniejszym.

Opisane powyżej zmiany nie byłyby jednak możliwe bez specyficznych, jak to określał Grzegorzewski, „przyrodzonych” Bułgarom cech. Opanowanie ziem bułgarskich przez Turków przerwało proces dynamicznego rozwoju organizmu

97 J.G. [J. Grzegorzewski], Szkolnictwo..., z. 10, s.175-176.

$98 \mathrm{Na}$ kwestię tę Grzegorzewski wielokrotnie zwracał uwagę w swoich pracach. Potwierdza to także opisany przez niego obyczaj: „Gdy dziecko pierwszy raz zjawia się w szkole, przynosi nauczycielowi w darze chustkę, w której węzełku pieniądze są zawiązane. Matka jednocześnie podaje jadło i mówi: Oto przyprowadzamy ci nasze dziecko (tu ogłasza jego imię) do nauki. Dajemy ci mięso, dajemy ci wszystko, jeno nie żałuj fatygi i zrób z niego człowieka. Zarazem zwraca się do dziecka: Słyszysz com mówiła i przekazywała nauczycielowi. Teraz obaczymy co on zrobi”, J. Grzegorzewski, Za Dunajem..., s. 155-156.

99 J.G. [J. Grzegorzewski], Szkolnictwo..., z. 8, s. 312.

$100 \mathrm{~W}$ miastach trwał on 10 miesięcy, natomiast na wsi był skracany do 7-8 miesięcy, tak aby dzieci mogły pomagać rodzicom w czasie żniw czy winobrania; ibidem, z. 10, s. 172.

101 Sytuacja ta uległa zmianie dopiero w 1909 r. 
państwowego, ale także wyeliminowało z życia społecznego jego elity polityczne $e^{102}$, a jednocześnie na niemal pięć wieków zepchnęło Bułgarów do rangi darmowej siły roboczej ${ }^{103}$. Tym samym ciężar kontynuowania tradycji historycznej i podtrzymywania ducha narodowego spadł na ludność wiejską. Ta jednak została upośledzona w swoich prawach i wykluczona $\mathrm{z}$ uczestnictwa w życiu społecznym ${ }^{104}$, a utrwalenie się i pogłębienie tej sytuacji w kolejnych dziesięcioleciach powodowała - podkreślaną przez Grzegorzewskiego wielokrotnie i wspomnianą wyżej - apatię i poczucie bezsilności, które z upływem czasu motywowały znaczną jej część do szukania możliwości dostosowania się do otaczającej rzeczywistości. Dlatego chłopstwo bułgarskie nie wyrażało zainteresowania działalnością polityczną i z niechęcią odnosiło się do pojawiających się coraz częściej na Bałkanach idei narodowowyzwoleńczych. Upadek ducha był tak znaczny, że - jak wspomina Grzegorzewski - na początku XIX w., kiedy różne czety powstańcze pojawiały się na ziemiach bułgarskich, „wójtowie i gromady wiejskie bułgarskie same o tem dawały znać Turkom i zdradzały własnych bojowników. Zdawali się wówczas ludzie mówić: «Dobrze nam nie jest, ale może być gorzej, gdy Turcy mścić się zechcą na nas; nie pogarszajcie losu naszego»" 105 . Tego typu postawa, jakkolwiek dominująca, nie była typowa dla całości społeczeństwa. Kontestowali ją m.in. tzw. hajducy, czyli ludzie, którzy skrzywdzeni przez urzędników czy turecki wymiar sprawiedliwości, uciekali w góry, gdzie tworzyli mniejsze lub większe oddziały partyzanckie ${ }^{106}$. Podejmowane przez nich akcje miały początkowo charakter osobistej zemsty, ale w miarę upływu czasu stawali się oni coraz częściej nosicielami idei narodowowyzwoleńczych i patriotycznych, które wzmacniały ducha narodowego i motywowały bułgarskie społeczeństwo do stawiania oporu okupantom. Zupełnie przeciwne tendencje reprezentowała natomiast grupa wywodząca się z zamożnego chłopstwa, tzw. czorbadży, która znacznie zwiększyła swoją liczebność w pierwszej połowie XIX w. „Byli to ludzie, którym się kłaniano, ale których nienawidzono, bo często krew i pot wysysali z ludu"107. Czorbadży, dążąc do zachowania swojego statusu

102 J. Grzegorzewski, Stronnictwa..., s. 81, 773; Bułgarya pod jarzmem..., z. 301, s. 12; K. Murzyński, Serbia i jej przodownictwo, „Niwa” 9 (1880), z. 124, s. 245.

103 J. Grzegorzewski, Za Dunajem..., s. 79. Jednocześnie na ludność wiejską nałożono drakoński system podatkowy, którego wymiar sukcesywnie się zwiększał; ibidem, s. 79-82.

104 J. Grzegorzewski, Spółczesna Bułgarya..., z. 3, s. 531, 546; idem, Za Dunajem..., s. 77-78. Jak pisał: Turcy ,jak każdy Muzułmanin wysoko cenili swoją wiarę mahometową i tych tylko mieli za ludzi, którzy ją wyznawali; innych nie uważali za stworzenia boskie, godne, by je traktować po ludzku. Stąd lekceważenie dla chrześcijan i pogarda dla nich; stąd wyniosłość i pycha”, Ibidem, s. 83; na ten temat także: Ze wsi i miast Macedonii i Starej Serbii, „Świat Słowiański” 9 (1913), nr 1, s. 285; Bułgarya pod jarzmem..., z. 301, s. 12.

105 J. Grzegorzewski, Za Dunajem..., s. 143.

106 Ibidem, s. 98; idem, Spółczesna Bułgarya..., z. 3, s. 545, S. Ciszewski, Wróżda i pojednanie. Studium etnologiczne, Warszawa 1900, s. 51, A. Zawilski, O wolność Bułgarii, Warszawa 1979, s. $18-19$.

107 J. Grzegorzewski, Za Dunajem..., s. 97. 
społecznego, często przyjmowali islam i stawali się lokalnymi funkcjonariuszami tureckiego aparatu sądowniczego i fiskalnego, a wiernie służąc władzom tureckim, oddawali im duże przysługi przy tłumieniu bułgarskiego ruchu hajduckiego, a potem narodowowyzwoleńczego.

Apatyczna postawa przeważającej części Bułgarów spowodowana była kilkoma czynnikami. Po pierwsze, brakiem wiary w możliwość odniesienia sukcesu w starciu z potęgą Wysokiej Porty, potem obawą przed zemstą, której Bułgarzy wielokrotnie doświadczali, przed destrukcyjnymi działaniami patriarchatu konstantynopolitańskiego ${ }^{108}$. Czynnikiem o kluczowym znaczeniu była wszakże ich - zdecydowanie większa niż u innych ludów bałkańskich - „orientalizacja”, będąca zarówno skutkiem kolonizacji protobułgarskiej, jak i geograficznym położeniem siedzib na pograniczu etniczno-kulturowym. Z tej przyczyny - jak stwierdził Grzegorzewski - w Bułgarach „sporo jest tej tajemniczości orientalnej, tych rysów właściwych kulturze wschodniej”"109. „Orientalizacja” ta wyrażała się nie tylko w zachowaniu, ale także w cechach fizjonomicznych - budowie ciała i rysach, które upodobniały ich do Turków i Tatarów, oraz w modzie ${ }^{110}$. „Gdy się spojrzy na takiego Bułgara, zwłaszcza gdy jest $\mathrm{w}$ fezie lub bez własnego innego nakrycia głowy [...], to niepodobna poznać Turek li to jest czy Bułgar"111. Podobnie jak Turcy, Bułgarzy wyróżniali się na Bałkanach wrodzoną powagą, chodzili i mówili powoli, dalecy byli od gwałtowności i rzadko wybuchli gniewem. Charakteryzowali się także dużą rozwagą w działaniu i rozmowach, a także przezornością i daleko posuniętą ostrożnością. Wspólną obu nacjom cechą była także prostota codziennego jadłospisu i wstrzemięźliwość od picia alkoholu oraz surowość obyczajów i wyjątkowa dbałość o czystość ducha i ciała ${ }^{112}$. Te liczne podobieństwa sprawiały, że Bułgarzy zdecydowanie częściej niż inne narody bałkańskie pozwalali sobie na spoufalanie się z Turkami, ale - jak pisał Grzegorzewski - „było w tem zachowaniu się więcej wyrachowania i musu, niż spodlenia lub układności i uniżoności greckiej”113.

108 J. Grzegorzewski, Spótczesna Bułgarya..., z. 3, s. 540.

109 Ibidem, z. 2, s. 201; idem, Stosunki..., s. 416.

110 Jak pisał Grzegorzewski: „Z wyjątkiem bowiem północno-zachodnich terenów kraju [...] wieśniak ubiera się tak samo jak chłop turecki: na nogach chodaki skórzane, niekiedy przymocowane rzemieniem, spodnie u dołu wąskie, u góry buchaste, obwisłe, torbiaste, zwieszające się do tyłu jakby worek [...]. Kurtka u Bułgara, krótka, tylko do pasa, często z rękawami rozciętymi na wyloty, uszyta jak i spodnie z grubego brunatnego sukna, zwanego $a b a$, lub u bogatszych z żółto-brunatnego szajaku; jedno i drugie obszyte lub szamerowane czarnemi taśmami szmuklerskimi, tak zwanym gajtanem. Po spodniach, a pod kurtką pas wełniany czerwony długości nieraz do 7 łokci i tak szeroki, że cały nim brzuch kilkakrotnie opasują", J. Grzegorzewski, Za Dunajem..., s. 182-184.

111 Ibidem, s. 182.

112 Ibidem, s. 39, 187.

113 Ibidem, s. 184-185. Bliższe kontakty ułatwiała także znajomość języka tureckiego wśród Bułgarów i bułgarskiego wśród Turków: „Nad Dunajem, nad Morzem Czarnem i w południowej Bułgaryi rozumieją i mówią niekiedy po turecku nie tylko chłopi, ale i kobiety wiejskie, natomiast w zachodniej Byłgaryi Turcy porozumiewają się z Bułgarami po bułgarski, bo znają tę mowę", ibidem, s. 177. 
Były jednak i różnice, wśród których poczesne miejsce zajmowały bułgarska pracowitość, oszczędność i niezrównany upór w dążeniu do założonych celów ${ }^{114}$. To właśnie te cechy - zdaniem polskiego badacza - wiodły Bułgarów do dobrobytu i majątku ${ }^{115}$, co szczególnie widoczne stało się po odzyskaniu niepodległości.

Peryferyjne położenie ziem bułgarskich wobec Imperium Osmańskiego sprawiło, że były one traktowane przez znaczną część okresu okupacji tureckiej, a zwłaszcza po wycofaniu się Turcji z aktywnej polityki europejskiej pod koniec XVII w., jako swego rodzaju strefa buforowa i zaplecze aprowizacyjne dla stolicy państwa. Stąd też Bułgaria aż do 1878 r. pozostawała prowincją niemal wyłącznie rolniczą ${ }^{16}$, a sytuacja ta nie zmieniła się także w pierwszych latach po reaktywacji państwowości ${ }^{117}$. Głębszym przemianom nie uległa także struktura wsi bułgarskiej, a powszechne przeżytki systemu tureckiego skutecznie hamowały postęp techniki rolniczej i wpływały na poziom gospodarowania ${ }^{118}$.

Dlatego też, zdając sobie sprawę z roli, jaką rolnictwo odgrywało w strukturze gospodarki, pierwsze władze bułgarskie podjęły działania na rzecz poprawy sytuacji na wsi. Ich istotnym elementem było zapatrzenie chłopów w ziemię, co stało się możliwe po wprowadzeniu w życie reformy rolnej w 1880 r., która stworzyła podstawy prawne i uregulowała przebiegający do tej pory żywiołowo proces przejmowania areałów z rąk masowo opuszczających Bułgarię Turków i Czerkiesów ${ }^{119}$. Mimo że działania te ustabilizowały sytuację, zmiany strukturalne miały ograniczony wymiar. Nadal dominowała mała własność ziemska ${ }^{120}$, a tylko ok. 55 tys. rolników spośród ogólnej liczby ponad 450 tys. chłopów gospodarowało na areałach od 10 do $15 \mathrm{ha}^{121}$. Niemniej jednak wzrost produkcji rolniczej, a co za tym idzie -

114 J. Grzegorzewski, Stosunki..., s. 417. Jak pisał, charakterystyczna była „wielka wytrzymałość, pracowitość i zapobiegliwość ludu bułgarskiego, z którym pod tym względem nikt w Europie spółubiegać się nie zdoła, bo chyba tylko Chińczykom ustępują", idem, Za Dunajem..., s. 179.

115 J. Grzegorzewski, Za Dunajem..., s. 39.

116 Kronika, „Świat Słowiański” 9 (1913), nr 1, s. 196; na ten temat także: M.I. Newbigin, Geographical Aspects of Balkan Problems in their Relation to the Great European War, London 1915, s. 212; W.S. Monroe, Bulgaria and Her People, Boston 1914, s. 288; W. Miller, Travels and Politics in the Near East, London 1898, s. 440; D. Davis, Bulgarian Mission of the Methodist Episcopal Church, New York 1906, s. 10.

117 Jeszcze na początku XX w. rolnictwem zajmowało się niemal 85\% ludności; Kronika, „Świat Słowiański” 8 (1913), nr 1, s. 196.

118 Ibidem, s. 196.

119 J. Grzegorzewski, Za Dunajem..., s. 323; C. Jireček, op. cit., s. 200.

120 Niemal połowa gospodarstw posiadała powierzchnię do 30 dekarów, ale ok. 1/4 Z nich miała areał do 1 dekara $\left(1\right.$ dekar $\left.=1000 \mathrm{~m}^{2}\right)$; C.G. Popoff, La Bulgarie économique 1879-1911, Sofia 1920, s. 110; M.I. Newbigin, op. cit., s. 212; W.K. Weiss-Bartenstein, Bulgarien, Land, Leute und Wirtschaft zur Zeit des Balkankrieges, Leipzig 1913, s. 177; na ten temat także: W.S. Monroe, op. cit., s. 289.

121 J. Grzegorzewski, Za Dunajem..., s. 338; Kronika, „Świat Słowiański” 8 (1913), nr 1, s. 196. Podatek gruntowy w wysokości przekraczającej 500 lewa rocznie płaciło tylko 822 właścicieli gospodarstw. 
zamożności mieszkańców, szybko przełożyły się na zmianę wyglądu zarówno ośrodków wiejskich ${ }^{122}$, jak i miast będących w tym czasie głównym odbiorcą plonów ${ }^{123}$.

Trzon gospodarki rolnej stanowiła uprawa zbóż $\dot{z}^{124}$ - pszenicy, jęczmienia, owsa, prosa i orkiszu, a także kukurydzy i ryżu ${ }^{125}$. Pod ich uprawę przeznaczano ok. 75\% ziemi, a roczna wydajność wynosiła $30 \mathrm{mln}$ hektolitrów ziarna ${ }^{126}$. Znaczną część ziemi, ok. 17,5\%, przeznaczano także na produkcję siana, a spośród innych roślin dużą wagę przywiązywano do upraw: bobu, winnej latorośli oraz warzyw i owoców ${ }^{127}$, głównie arbuzów i melonów, a także kalafiorów, kabaczków, soczewicy i karczochów, które powszechnie znano i wysoko ceniono na rynkach europejskich ${ }^{128}$. Ważne miejsce w produkcji rolniczej zajmowały także uprawy konopi i lnu oraz róż. Jakkolwiek ta ostatnia zajmowała zaledwie $0,2 \%$ ogólnej powierzchni areałów, w niektórych regionach stanowiła uprawę wiodącą w hodowli roślin. Jak pisał Grzegorzewski: „za Płowdiwem ku Rodopom [...] całe pola od Pesztery do Stanimaki są różane, nic tylko same róże: wyglądają jak jeden bez końca kobierzec różany; drugie takie przestrzenie róż na południu Bałkany i Średniej Góry, najbardziej w dolinach Kazanłyckiej i Karłowskiej; jak u nas pszenicą i żytem, tak tam zasiane są całe pola różami tak, że aż łuna od nich bije na niebo błękitne"129.

Uprawy te dostarczały podstawowego surowca do produkcji olejku różanego ${ }^{130}$, który był jednym z najważniejszych bułgarskich towarów eksportowych. Mniejsze

122 J. Grzegorzewski, Za Dunajem..., s. 351; Kronika, „Świat Słowiański” 8 (1913), nr 1, s. 327.

123 J. Grzegorzewski, Stosunki..., s. 417-418; Kronika, „Świat Słowiański” 7 (1907), nr 2, s. 192.

124 W.S. Monroe, op. cit., s. 289. Wartość produkowanego w Bułgarii zboża szacowano na ok. 340 mln lewa; Kronika, „Świat Słowiański” 8 (1913), nr 1, s. 196.

125 J. Grzegorzewski, Za Dunajem..., s. 318-319; Recenzye i sprawozdania, „Świat Słowiański” 7 (1911), nr 1, s. 226.

$1261 \mathrm{hl}$ ziarna $=$ ok. $70 \mathrm{~kg}$.

127 Uprawę warzyw i owoców Bułgarzy opanowali do perfekcji. Stąd też w miarę upływu czasu stawali się pożądanymi specjalistami nie tylko na Bałkanach, ale także w całej Europie Środkowej, w tym w Galicji i Królestwie Polskim, które odwiedzali często jako tzw. wędrowni ogrodnicy. Jak podaje Grzegorzewski, zajęciem tym trudniło się co roku 12 tys. ludzi; J. Grzegorzewski, Za Dunajem..., s. 347-348.

128 Recenzye i sprawozdznia, „Świat Słowiański” 7 (1911), nr 1, s. 227; na ten temat także: A. Piotrowski, $Z$ dziejów Carstwa Bułgarskiego. Wspomnienia osobiste, „Tygodnik Ilustrowany” 42 (1908), s. 848; W.S. Monroe, op. cit., s. 289; W.K. Weiss-Bartenstein, op. cit., s. 177; C. Jireček, op. cit., 176.

129 J. Grzegorzewski, Za Dunajem..., s. 33-34.

130 Produkcja olejku różanego była bardzo opłacalna. „Funt takiego olejku w handlu hurtowym kosztuje mniej więcej 200 guldenów, a maleńki flakonik po 15-20 koron, i to najwyżej już z domieszką olejku bergamotowego lub geraniowego, a czysty różany jeszcze drożej”, J. Grzegorzewski, Za Dunajem..., s. 332. Dla porównania, przychody gminy Dzików w Galicji w 1872 r. wnosiły 198 złr. (guldenów), a pisarz gminny w tym czasie pobierał 15 złr. (30 koron) rocznie; J. Słomka, Pamiętniki włościanina, Kraków [1929], s. 166, 211; na ten temat także: A. Bezenšek, op. cit., s. 104-106; Z. Przesmycki, op. cit., s. 425-426; C. Jireček, op. cit., 180-181; M.I. Newbigin, op. cit., s. 212-213; W. Miller, op. cit., s. 444; W.S. Monroe, op. cit., s. 290; W.K. WeissBartenstein, op. cit., s. 177; J.F. Fraser, Pictures from the Balkan, Londyn 1906, s. 93-99. 
znaczenie $\mathrm{w}$ tym czasie miała natomiast produkcja tytoniu i bawełny ${ }^{131}$. Obok uprawy roślin ważnym elementem produkcji rolniczej była hodowla zwierząt. Największą popularnością cieszyło się bydło mięsne i mleczne oraz wykorzystywane do prac polowych bawoły ${ }^{132}$, a oprócz nich owce, których populacja w pierwszych latach po odzyskaniu niepodległości szacowana była na ok. 7 mln sztuk, kozy, osły i drób, w tym obok kur hodowane głównie w północno-wschodniej części kraju bażanty ${ }^{133}$. Jakkolwiek bułgarskie rolnictwo po $1878 \mathrm{r}$. przechodziło intensywny rozwój, co wydatnie wpływało na dynamiczny wzrost dochodów państwa w związku z tworzącymi się możliwościami eksportu płodów rolnych, sposoby uprawy roli pozostawały w niektórych jej częściach bardzo prymitywne ${ }^{134}$. Stąd też władze dokładały starań, aby zainteresować chłopów nie tylko nowymi formami gospodarowania, ale także mechanizacją rolnictwa ${ }^{135}$. Działania te podyktowane były z jednej strony dużą zapobiegliwością i głęboką troską o najistotniejszy sektor gospodarki, a $\mathrm{z}$ drugiej - możliwościami prowadzenia nieskrępowanej wymiany towarowej z całym światem, jakie stworzyło reaktywowanie państwowości.

Chociaż - jak pisał Grzegorzewski - „Bułgarzy mają uprzedzenie i pewnego rodzaju nieufność graniczącą ze wstrętem do cudzoziemców - i niechętnie jakoby kupują ich towary"136, wartość importowanych do Bułgarii towarów zagranicznych już w 1879 r. wyniosła ponad $32 \mathrm{mln}$ lewów. W roku następnym wzrosła o 50\%, a w $1881 \mathrm{r}$. osiągnęła poziom niemal $60 \mathrm{mln}$ lewów. Jakkolwiek stało to w sprzeczności ze wskazaną powyżej narodową cechą, import produktów zagranicznych bardzo szybko zaczął cieszyć się zainteresowaniem władz i kuratelą odpowiednich urzędów, ze względu na znaczne dochody, jakie czerpał skarb państwa z ceł wwozowych, szacownych na 3 do $5 \mathrm{mln}$ lewów ${ }^{137}$. Jednocześnie dokładano starań, aby obywatelom zapewnić dostęp do wszystkich potrzebnych im artykułów, a rodzącemu się przemysłowi podaż tych surowców, które w Bułgarii nie występowały. Stąd też w pierwszym okresie po $1878 \mathrm{r}$. najistotniejszym towarem importowym była sól, którą sprowadzano przede wszystkim z pobliskiej Rumunii, za niemal 15 mln lewów rocznie. Na kolejnych miejscach znalazły się: przędze i wyroby bawełniane $\left(5,5 \mathrm{mln}\right.$ ) maszyny i urządzenia $\left(\mathrm{ok} .4 \mathrm{mln}\right.$ ), towary norymberskie ${ }^{138}$ (ok. $2 \mathrm{mln}$ ), cukier ( $2 \mathrm{mln}$ ), a dalej: wyroby wełniane, napoje alkoholowe, materiały budowlane, wyroby metalowe, skóry garbowane, kawa i inne. Ogółem do Bułgarii

131 J. Grzegorzewski, Za Dunajem..., s. 327-328.

132 Ibidem, s. 337-338.

133 Ibidem, s. 35-36.

134 Recenzye i sprawozdania, „Świat Słowiański” 7 (1911), nr 1, s. 227; Z. Przesmycki, op. cit., s. 423-424; L. Pasvolsky, op. cit., s. 25-26; C. Jireček, op. cit., 174-175; W.S. Monroe, op. cit., s. 288; D. Davis, op. cit., s. 12.

135 J. Grzegorzewski, Za Dunajem..., s. 341-343.

136 J. Grzegorzewski, Stosunki..., s. 418.

137 Ibidem, s. 420.

138 Mianem towarów norymberskich określano drobną, ręcznie wykonywaną galanterię, zabawki oraz niewielkie przedmioty domowego użytku. 
w latach 1880-1881 sprowadzano 72 typy towarów, głównie z Austro-Węgier, Wielkiej Brytanii, Turcji, Włoch, Francji, Rosji i Niemiec ${ }^{139}$. Nie ulega jednak wątpliwości, że największym partnerem Bułgarii w tym czasie była monarchia habsburska. Import austriacki obejmował 54 spośród wszystkich typów produktów, wśród których znalazły się tkaniny, maszyny, alkohole, a nawet galanteria i biżuteria. $\mathrm{Na}$ taki stan rzeczy istotny wpływ miała $\mathrm{z}$ jednej strony coraz bardziej widoczna koncepcja rozluźnienia więzów łączących Bułgarię z Rosją i zbliżenia do mocarstw zachodnich, reprezentowana zarówno przez Aleksandra Battenberga, jak i kręgi rodzącej się burżuazji bułgarskiej, a z drugiej strony - atrakcyjność cenowa proponowanych przez Austro-Węgry towarów ${ }^{140}$. Ta utrwalona w pierwszych latach po odzyskaniu niepodległości tendencja utrzymywała się przez kilka dziesięcioleci, aż do wybuchu wojen bałkańskich w 1912 r., co zresztą Grzegorzewski przewidywał ${ }^{141}$.

Bułgarzy nadzwyczaj pochopni są do postępu, który u nich zadziwiająco szybkie robi kroki. Zaledwo minął rok od obrad kongresu berlińskiego, który otworzył przystęp Europie do Bułgaryi, a metamorfoza tego kraju zaczęła się odbywać jakby za uderzeniem różdżki czarodziejskiej: miasta zamieniały swoją fizyognomię, a ludzie przekształcali się nie do poznania, zrzucając swój strój dotychczasowy i zmieniając go na europejski, przyswajając sobie nowe potrzeby, nowe warunki życia $[\ldots]^{142}$.

Tym samym Bułgaria wkroczyła na drogę nowoczesnego rozwoju, który, jak wspomniano, postawił ją na czele państw regionu, czyniąc z niej ważnego partnera w skali europejskiej. Nie byłoby to możliwe bez narodowego odrodzenia społeczeństwa, bez uporu i konsekwencji w działaniu i bez rozsądnej polityki kolejnych bułgarskich gabinetów. Poznanie tego procesu z polskiej perspektywy i śledzenie jego przebiegu byłoby niewątpliwie mocno utrudnione, gdyby nie dzieła pozostawione przez Jana Grzegorzewskiego - wybitnego znawcę i wielkiego przyjaciela Bułgarów i Bułgarii.

\section{Bulgarians and Bulgaria in the Last Quarter of the $19^{\text {th }}$ Century in the Publications of Jan Grzegorzewski (Culture, Population, Economy)}

\section{Abstract}

The seizure of the Bulgarian lands by the Turks at the end of the $14^{\text {th }}$ century brought up many deep and multifaceted changes for the Bulgarians. It marked the end not only of their flourishing state, which at times had counterbalanced the Byzantine Empire, but mainly of their political elites which would provide the foundations for their struggle for independence. For this

139 J. Grzegorzewski, Stosunki..., s. 421.

140 Jak pisał Grzegorzewski: „Jeśli w Filipopolu lub Sofii parę butynków wiedeńskich kupić można za 10-12 franków, a za rosyjskie lub miejscowego wyrobu płacić trzeba 20-24 franków, to konkurencya dla wyższych cen jest nader trudną, choćby nawet inne warunki towaru (np. dobroć i trwałość jego) były po stronie tych ostatnich", ibidem, s. 426.

141 Ibidem, s. 428-429.

142 Ibidem, s. 428. 
reason, with the lapse of time, Bulgarian rural population, burdened with draconian obligations and pushed aside on the margin of social life, sank deeper and deeper in apathy, growing in impotence. A change in the situation occurred only at the turn of the $19^{\text {th }}$ century, when a process of national revival began in the Bulgarian lands. Not only did the process revive a national spirit in the Bulgarians and motivate them to fight, but also filled them with a sense of dignity, which made it possible for them soon after they regained independence to place their country at the lead of the region. Those dynamic changes were observed by the outstanding and excellent Polish Slavic philologist and Orientalists Jan Grzegorzewski during his voyages throughout the Bulgarian lands; all his observations and impressions he described in several books and essays published in popular papers and periodicals. The image of Bulgaria of the end of the $19^{\text {th }}$ century has been still a valuable source of information both for historians and for other scholars.

\section{Болгары и Болгария в последней четверти XIX в. в публикациях Яна Гжегожевского (культура, население, экономика)}

\section{Аннотация}

Овладение болгарскими землями турками к концу XIV в. принесло болгарам глубокие и многоаспектные перемены. Оно являлось не только концом их процветавшего в более ранний период государства, которое временно являлось даже противовесом Византийской империи, но, прежде всего, лишило их политической элиты, опираясь на которую было бы возможным вступить в борьбу за независимость. Из-за этого также деревенское население, обремененное драконовскими повинностями и маргинализированое в социальной жизни, с течением времени, все глубже погружалось в апатию и убеждалось в бессилии. Обстановка изменилась только на рубеже XVIII и XIX в., когда на болгарских землях начался процесс национального возрождения. Этот процесс не только возродил в болгарах национальный дух и смотивировал их на вступление в борьбу за их законные права, но также переполнил их чувством собственного достоинства, что после обретения независимости позволило им в короткое время поставить страну во главе государств региона. За этими динамическими изменениями наблюдал во время своих многократных путешествий по болгарским землям выдающийся польский славист и ориенталист Ян Гжегожевский. Он описал свои впечатления в нескольких книгах и статьях, помещенных в популярных периодических изданиях. Созданный им образ Болгарии конца XIX в. до настоящего времени является неоценимым источником знаний как для историков так и для представителей других научных дисциплин.

\section{Bibliografia}

Bezenšek A., Bolgarija in Srbija, Celovec 1897.

Bułgarya pod jarzmem tureckim, „Niwa” 16 (1887), z. 301, 302.

Chłoniewski A., Nieśmiertelni. Fotografie literatów lwowskich, Lwów 1898.

Ciszewski S., Wróżda i pojednanie. Studium etnologiczne, Warszawa 1900.

Czarnowski S.J., Dziennikarstwo słowiańskie i polskie, Kraków 1895.

Davis D., The Bulgaria Mission of the Methodist Episcopal Church, New York 1906.

Dobosz K., Początki i pierwszy tom Rocznika Orientalistycznego. Przyczynek do dziejów czasopisma, „LingVaria” 7 (2012), nr 2.

Fraser J.F., Pictures from the Balkan, London 1906. 
Grzegorzewski J., Albania i Albańczycy, Lwów 1914.

G[rzegorzewski] J., Dragan Cankow, „Świat Słowiański” 7 (1911), nr 1.

Grzegorzewski J., Dwa fermany sultańskie z XVIII w. Zarys historyczny traktatów handlowych Polski z Turcya, „Rocznik Orientalistyczny” 1916-1918.

G[rzegorzewski] J., Echa zjazdu sofijskiego, „Świat Słowiański” 7 (1911), nr 1.

Grzegorzewski J., Ein türk-tatarischer Dialekt in Galizien: Vokalharmonie in den entlehnten Wörtern der karaitischen Sprache in Halicz, „Sitzungsberichte der Kaiserlichen Akademie der Wissenschaften Philosophisch-Historische Klasse” 146 (1903), Abh. 1.

Grzegorzewski J., Ferman sultana Abdulhamida I z r. 1775, w: Księga pamiątkowa ku uczczeniu czterdziesto-pięcioletniej pracy literackiej prof. dr Józefa Tretiaka, Kraków 1913.

Grzegorzewski J., Grób Warneńczyka: badania autentyczności grobu przy 4-tym kilometrze pobojowiska warneńskiego $z$ d. 10-go listopada 1444 r., z 14 załacznikami, Kraków 1911.

Grzegorzewski J., Jezyk Łach-Karaitów. Narzecze południowe (łucko-halickie), Kraków 1917.

Grzegorzewski J., Na Spiszu. Studya i teksty folklorystyczne, Lwów 1919.

G[rzegorzewski] J., O „Echa zjazdu sofijskiego”, „Świat Słowiański” 7 (1911), nr 1.

Grzegorzewski J., Penczo Sławejkow, „Świat Słowiański” 8 (1912), nr 2.

Grzegorzewski J., Rok przewrotów (Bułgarya 1885/6), Lwów 1900.

Grzegorzewski J., Siedmiomiesięczna walka o samoistność Bułgaryi, „Świat Słowiański” 8 (1912), nr 1.

Grzegorzewski J., Spótczesna Bułgarya, „Ateneum” 8 (1883), nr 2, z. 2, 3.

Grzegorzewski J., Stosunki handlowe z Bułgarya, „Przegląd Powszechny” 4 (1887), z. 1.

Grzegorzewski J., Stronnictwa bułgarskie po przewrotach, „Świat Słowiański” 8 (1912), nr 2.

Grzegorzewski J., Stronnictwa bułgarskie za Aleksandra Battenberga, „Świat Słowiański” 7 (1911), nr 2.

J.G. [J. Grzegorzewski], Szkolnictwo w Bułgaryi, „Przegląd Powszechny” 4 (1887), z. 8, 10, 11.

Grzegorzewski J., Za Dunajem (Bułgarya, Serbia, Czarnogóra), Lwów 1904.

Grzegorzewski J., Z kresów Połabskich, Kraków 1885.

Grzegorzewski J., Z sydżyllatów rumelijskich epoki wyprawy wiedeńskiej akta tureckie, Lwów 1912.

Hołubowicz J., Bułgarya, jej przeszłość dziejowa i jej obecne narodowe i religijne odrodzenie, Kraków 1885.

Hoszowska M., Ludwik Finkel i Akademia Umiejętności. Z dziejów wspótpracy naukowej Lwowa i Karkowa na przełomie XIX i XX wieku, Rzeszów 2011.

История славеноболгарская, Sofija 1961.

Jankowski C., Na gruzach Turcji. Zarysy polityczno-publicystyczne, Warszawa 1915.

Jireček C., Geschichte der Bulgaren, Praga 1876.

Kaczmarek U., Jan Grzegorzewski - „pierwszy” polski orientalista, „Sprawy Wschodnie” 2002, nr 1.

Kaczmarek U., Wystawa poświęcona prof. Tadeuszowi S. Grabowskiemu i prof. Janowi Grzegorzewskiemu, Sofia, 24 czerwca 1996, „Etnografia Polska” 41 (1997), z. 1-2.

Каравълчев В., Холмската мисия на Йосиф Соколски и краят на Брест-литовската уния, „Християнство и култура” 9 (2011).

Каравълчев В., Някои бележки върху тичността на пьрвия униатски архиеп. Йосиф Соколски, „Християнство и култура” 7 (2011).

Kizilov M., Jan Grzegorzewski's Karaite materials in the archive of the Polish Academy of Sciences in Kraków, „Karaite Archives” 1 (2013).

Klejn Z., Polskie stronice w bułgarskiej historii, „Mazowieckie Studia Historyczne” 2 (1998).

Klejn Z., Polskie ślady w budowie nowożytnej Bułgarii, Łowicz 1999.

Манафова Р., Културното развитие на България при временното руско управление (18771879), w: Известия на Института за история, т. 29: Из историята на българската наука, просвета и култура през ХІХ и ХХ в., 1986. 
Miller W., Travels and Politics in the Near East, London 1898.

Monroe W.S., Bulgaria and Her People, Boston 1914.

More R.J., Under the Balkans. Notes of a Visit to the District of Philippopolis in 1876, London 1877.

Murzyński K., Serbia i jej przodownictwo, „Niwa” 9 (1880), z. 124.

Newbigin M.I., Geographical Aspects of Balkan Problems in their Relation to Great European War, London 1915.

Piotrowski A., Z dziejów Carstwa Bułgarskiego. Wspomnienia osobiste, „Tygodnik Ilustrowany” $42(1908)$.

Popoff C.G., La Bulgarie économique 1879-1911, Sofia 1920.

Przesmycki Z., Rumelia Wschodnia, „Ateneum” 10 (1885), t. 4.

Reychman J., O wykorzystanie źródeł orientalnych do historii Polski, „Przegląd Historyczny” 58 (1967), nr 2.

Reychman J., Peleryna, ciupaga i znak tajemny, Kraków 1971.

Reychman J., W ośrodkach orientalnych i orientalistycznych Bułgarii, „Przegląd Orientalistyczny” 21 (1957), nr 1.

Reychman J., Zasługi Jana Grzegorzewskiego na polu zbliżenia kulturalnego polsko-bułgarskiego, w: Stosunki literackie polsko-bułgarskie, red. J. Śliziński, Wrocław 1971.

Rubacha J., Obraz przemian politycznych w Bułgarii w ksiażce Jana Grzegorzewskiego „Rok przewrotów. (Bułgarya 1885/6)”, w: Wokół reportażu podróżniczego, red. D. Rott, Katowice 2007.

Rubacha J., Malinowski A., Giza A., Historia Bułgarii 1870-1915. Materiały źródłowe z komentarzami, Warszawa 2004.

Sława T., Propaganda unicka w Bułgaryi, „Świat Słowiański” 9 (1913), t. 2.

Słomka J., Pamiętniki włościanina, Kraków [1929].

Sopodźko T., O czasopismach w Bułgaryi, „Przegląd Powszechny” 8 (1891), nr 29.

Stacya naukowa polska na Wschodzie Hyacinthaeum, Warszawa 1916.

„Świat Słowiański” 3, 7-9 (rubryki: „Kronika”, „Przegląd prasy słowiańskiej”, „Recenzje i sprawozdania").

Tyszkiewicz J., Jan Grzegorzewski w ostatnich latach życia: 1916-1922, „Almanach Karaimski” 4 (2015).

Wegnerowicz W.R., Odrodzenie Bułgaryi, „Literatura i Sztuka. Dodatek do Dziennika Poznańskiego" 48 (1912).

Weiss-Bartenstein W.K., Bulgarien, Land, Leute und Wirtschaft zur Zeit des Balkankrieges, Leipzig 1913.

Zawilski A., O wolność Bułgarii, Warszawa 1979.

Zankow S., Die Grundlagung der Vefassung der bulgarischen orthodoxen Kirche, Zürich 1917.

Zborowski J., Historia pewnej książki. Wspomnienie o Janie Grzegorzewskim, „Rocznik Podhalański" 5 (1992).

Ze wsi i miast Macedonii i Starej Serbii, „Świat Słowiański” 9 (1913), nr 1.

Jarosław Rubacha, dr hab., historyk, bałkanista, pracownik Instytutu Dziennikarstwa i Komunikacji Społecznej Uniwersytetu Warmińsko-Mazurskiego w Olsztynie; zajmuje się historią Półwyspu Bałkańskiego w XIX i XX w., historią Bułgarii i polskim słowianofilstwem na początku XX stulecia (j.rubacha@wp.pl).

Jarosław Rubacha, holder of a post-doctoral degree, historian of the Balkans; his research interests focus on: the history of the Balkan Peninsula in the $19^{\text {th }}$ and $20^{\text {th }} \mathrm{cc}$., history of Bulgaria and Polish Slavophilia in the early 20 ${ }^{\text {th }}$ c. (j.rubacha@wp.pl). 